\title{
Production of branched tetraether lipids in the lower Pearl River and estuary: effects of extraction methods and impact on bGDGT proxies
}

\author{
Chuanlun L. Zhang ${ }^{1,2}{ }^{*}$, Jinxiang Wang ${ }^{1,3}$, Yuli Wei ${ }^{1}$, Chun Zhu ${ }^{1,4}$, Liuqin Huang ${ }^{5}$ and Hailiang Dong ${ }^{5,6}$ \\ 1 State Key Laboratory of Marine Geology, Tongji University, Shanghai, China \\ ${ }^{2}$ Department of Marine Sciences, University of Georgia, Athens, GA, USA \\ ${ }^{3}$ School of Earth Resources, China University of Geosciences-Wuhan, Wuhan, China \\ ${ }^{4}$ MARUM - Centre for Marine Environmental Sciences, University of Bremen, Bremen, Germany \\ ${ }^{5}$ Geomicrobiology Laboratory, State Key Laboratory of Geological Processes and Mineral Resources, China University of Geosciences, Beijing, China \\ ${ }^{6}$ Department of Geology, Miami University, Oxford, $\mathrm{OH}$, USA
}

\section{Edited by:}

Josh David Neufeld, University of Waterloo, Canada

Reviewed by:

Francien Peterse, ETH Zurich, Switzerland

Ping'An Peng, Guangzhou Institute of Geochemistry, China

*Correspondence:

Chuanlun L. Zhang, State Key Laboratory of Marine Geology, Tongji University, Shanghai 200092, China. e-mail: archaea.zhang@gmail.com
Branched glycerol dibiphytanyl glycerol tetraethers (bGDGTs) are known as bacterial lipids that occur widely in terrestrial environments, particularly in anaerobic peat bogs and soil. We examined the abundance and distribution of bGDGTs in both core $(C)$ and polar (P) lipid fractions from the water column and surface sediments in the lower Pearl River (PR) and its estuary using two extraction methods (sonication vs. Bligh and Dyer). A number of soil samples in the lower PR drainage basin were also collected and extracted for bGDGTs using the sonication method. The results showed aquatic production of bGDGTs as supported by substantial abundances of P-bGDGTs in the water column and sediment samples. The bGDGT-based proxies (BIT, CBT, and MBT) were not affected by the method of extraction when $\mathrm{C}-\mathrm{bGDGT}$ s were analyzed; in such case, the $\mathrm{pH}_{\mathrm{CBT}}$ of the sediments reflected the soil $\mathrm{pH}$ of the lower PR drainage basin, and the temperature close to the annual mean air temperature (MAT) in the lower PR basin. On the other hand, the P-bGDGT-derived proxies were inconsistent between the two methods. The P-bGDGTs (particularly those extracted using the sonication method) may not be reliable indicators of annual MATs.

Keywords: Pearl River, estuary, bGDGTs, paleoclimate proxies

\section{INTRODUCTION}

Rivers and coastal regions play a key role in the global biogeochemical cycle of carbon because they represent a fundamental, multi-faceted link between the atmosphere, land, and ocean (Raymond and Cole, 2003; Cole et al., 2007; Mayorga, 2008). Rivers are known to be the main channels delivering terrestrial particulateand dissolved organic matter into the ocean as the majority of the global burial of organic carbon in the ocean is found in margins adjacent to rivers (e.g., Hedges and Keil, 1995; Goni et al., 2006). Increasing evidence further indicates that rivers may constitute a moving bioreactor with interactions occurring between microbial communities and the river organic and/or inorganic constituents (e.g., Dagg et al., 2005; Duan and Bianchi, 2006).

Estuaries are dynamic environments where the transportation of terrestrial organic matter from rivers to oceans occurs, and water chemistry changes dramatically between ocean and river environments. The composition of organic matter can also change in the estuary as a result of mixing and enhanced physical, chemical, and microbial reworking of the organic matter (Hedges et al., 1988; Zimmerman and Canuel, 2001; Zhu et al., 2011a).

Recently a number of novel proxies have been developed that are thought to reflect terrestrial environmental signals because biomarkers constituting these novel proxies are known to be ubiquitously and predominantly produced in soil and peat bogs
(Hopmans et al., 2004; Weijers et al., 2006a, 2007a). These include methylation index of branched tetraethers (MBT), cyclization ratio of branched tetraethers (CBT) and branched and isoprenoid tetraethers (BIT), which all consist of glycerol dialkyl glycerol tetraethers (GDGTs; Hopmans et al., 2004; Weijers et al., 2007a). CBT and MBT utilize compounds produced by organisms of unknown origin but appear to be from bacteria found in terrestrial environments (Weijers et al., 2006b; Sinninghe Damsté et al., 2011). In particular, CBT is known to reflect soil $\mathrm{pH}$ (Weijers et al., 2007a; Peterse et al., 2009) and CBT and MBT in combination can reflect annual mean air temperature (MAT; Weijers et al., 2007a; Sun et al., 2011). These proxies have been increasingly used for past continental temperature (Weijers et al., 2007b,c, 2011; Ballantyne et al., 2010; Peterse et al., 2011; Zhou et al., 2011) or pH (Weijers et al., 2007b; Tyler et al., 2010; Fawcett et al., 2011; Zhou et al., 2011) determinations as well as for paleotemperature determinations in continental margins (Weijers et al., 2007b,c; Schouten et al., 2008; Rueda et al., 2009; Bendle et al., 2010) or lakes (Tyler et al., 2010; Zink et al., 2010).

The BIT index was originally developed to reflect the relative abundances of marine crenarchaeol and terrestrial branched tetraethers in a marine setting, which serves as a unique proxy for transport of terrestrial carbon to marine environments (Hopmans et al., 2004). An increasing number of studies have used BIT to 
address transport of terrestrial organic matter from rivers into the marine system (Herfort et al., 2006; Kim et al., 2006, 2007, 2009, 2010; Huguet et al., 2007; van Dongen et al., 2008; Walsh et al., 2008; Belicka and Harvey, 2009; Schmidt et al., 2010; Smith et al., 2010; Zhu et al., 2011b). A general observation of these studies is that the terrestrial organic matter preserved in marine sediments as estimated by BIT reflects mostly soil origin (Walsh et al., 2008; Belicka and Harvey, 2009; Weijers et al., 2009). On the other hand, crenarchaeol is known to be present in soil (e.g., Leininger et al., 2006), lakes (e.g., Powers et al., 2004), rivers (e.g., Herfort et al., 2006), and terrestrial hot springs (Pearson et al., 2004; Zhang et al., 2006), which can complicate the interpretation of BIT in certain geological settings.

All of those studies focused on the core lipids of bGDGTs. Recently, intact polar lipids (IPL) of bGDGTs have been examined in soil or peat bogs (Liu et al., 2010; Peterse et al., 2010; Weijers et al., 2011) and a lake (Tierney et al., 2011). The IPL of bGDGTs are lower in abundance than the core lipids of bGDGTs in soil (Peterse et al., 2010; Weijers et al., 2011) or peat (Liu et al., 2010) but respond similarly to $\mathrm{pH}$ variations as do the core lipids in soil (Peterse et al., 2010). Mounting evidence indicates that branched tetraether lipids can be produced in situ in aquatic environments including fjords (Peterse et al., 2009), lakes (Sinninghe Damsté et al., 2009; Tierney and Russell, 2009; Sun et al., 2011; Tierney et al., 2011; Wang et al., 2012), and estuaries (Zhu et al., 2011b). These observations warn that cautions should be exercised when using BIT, CBT, or MBT as proxies for soil input into marine or lacustrine sediments or for estimating changes in paleo-air temperatures of continental settings.

The Pearl River is the second largest river in China and together with the Mekong River it provides the largest inflow of fresh water to the South China Sea (Hu et al., 2006a, 2009). It discharges $\sim 3.26 \times 10^{11} \mathrm{~m}^{3}$ of fresh water and $\sim 7 \times 10^{7}$ tons of sediment annually to the South China Sea. However, $80 \%$ of the sediment is estimated to be deposited within the Pearl River estuary (Wai et al., 2004). A number of studies have examined the terrestrial inputs of organic matter to the Pearl River estuary and adjacent South China Sea by looking at dissolved organic carbon (e.g., Callahan et al., 2004; Chen et al., 2004; Hu et al., 2006a), particulate organic carbon (e.g., Chen et al., 2003), or sedimentary organic matter (He et al., 2010; Yu et al., 2010). Molecular biomarker studies show increased terrestrial signals from the Pearl River mouth to the inner estuary and enhanced marine conditions further offshore (Hu et al., 2006b, 2009).

Here we present initial measurements of both core lipids and polar lipids (PL; see the definition of PLs in Material and Methods) of branched GDGTs from the lower Pearl River to the estuary. Our goal was to delineate the sources of bGDGTs in estuary environments and evaluate the potential use of these biomarkers for paleo-continental climate studies in the region. In particular, the PLs can add additional insight into the sources of the in situ production of bGDGTs in these systems. We chose the Pearl River for examining the sources and distribution of bGDGTs because this system has been well characterized in terms of the distribution and degradation of terrestrial organic matter, which would provide a good context for studying the bGDGT-dynamics at the land-sea interface. Our results show in situ production of
bGDGTs in the lower Pearl River and the estuary, with a significant decrease in the abundance of core lipids from fresh water to brackish water. The $\mathrm{pH}$ of the sediments as calculated from core (C)-bGDGTs-derived CBT reflects the soil environment of the lower Pearl River drainage basin, and the temperatures recorded by the C-bGDGTs in the sediments reflect the annual MATs of the lower Pearl River drainage basin. On the other hand, temperatures calculated from the polar (P)-bGDGTs are significantly lower than those from the C-bGDGTs, suggesting that P-bGDGTs (particularly those extracted using the sonication method) may not be reliable indicators of annual MATs.

\section{MATERIALS AND METHODS DESCRIPTION OF FIELD SITE}

The lower Pearl River is a complex water system that consists of three main tributaries: Beijing (North River), Dongiiang (East River) and Xijiang (West River; Figure 1). Discharge of freshwater by the Pearl River goes through three sub-estuaries: Lingdingyang, Modaomen and Huangmaohai (Figure 1). Nearly half of the freshwater flows through Lingdingyang, which is a North-South bell-shaped area with a length of about $49 \mathrm{~km}$ and a width varying from 4 to $48 \mathrm{~km}$ (Hu et al., 2006a, 2009). The average water depth of the Lingdingyang is $4.8 \mathrm{~m}$, increasing from north to south and west to east (Hu et al., 2009). The average tidal range is $1-2 \mathrm{~m}$ and the tidal current is $1-2 \mathrm{~m} / \mathrm{s}$ (Hu et al., 2009). The sedimentation rates vary in the estuary/shelf system, with $1.13-2.34 \mathrm{~cm} /$ year in the coastal regions (Jia and Peng, 2003) and $0.2-1.0 \mathrm{~cm} /$ year on the shelf (Owen and Lee, 2004). The age of the surface sediment (the top $10 \mathrm{~cm}$ ) is estimated to be $5-10$ years in the estuary/shelf system (Hu et al., 2006a).

The lower Pearl River region is characterized by humid subtropical weather with annual MAT of about $22^{\circ} \mathrm{C}$ and annual precipitation of $1200-2200 \mathrm{~mm}$ (Zhang et al., 2008). Vegetation in this tropical region is dominated by $\mathrm{C} 3$ plants with $\mathrm{C} 4$ grasses being a minor component; however, sugarcane (a C4 plant) is one of the major agricultural products in the region today (Yu et al., 2010). Soil pH in this region ranges from 4.07 to 7.22 (Wong et al., 2002).

\section{COLLECTION OF WATER, SEDIMENT, AND SOIL SAMPLES}

A cruise in July 2010 collected samples in the Beijing tributary and the Lingdingyang estuary (Figure 1). Water samples were collected at 14 stations, which included 10 in the lower Pearl River and 4 in the estuary (Table 1). The river stations included both main channel and sub-tributary samples. Samples from the estuary were collected from both surface and bottom water layers.

At each station in the river, water at a depth of $1-3 \mathrm{~m}$ was collected into a 200-L plastic barrel using a submersible pump. The barrel was rinsed with the river water three times before being filled. The pump was then connected to a filtration system that held three 142-mm glass-fiber filters in parallel. The filters had been combusted at $450^{\circ} \mathrm{C}$ overnight and weighed individually at room temperature prior to the cruise. The total volume of water for all three filters was recorded and the filters were then carefully transferred to sterile $50-\mathrm{mL}$ centrifuge tubes, which were immediately stored in a liquid nitrogen container. Finally, suspended particulate matter was collected using $0.45-\mu \mathrm{m}$ filters by 


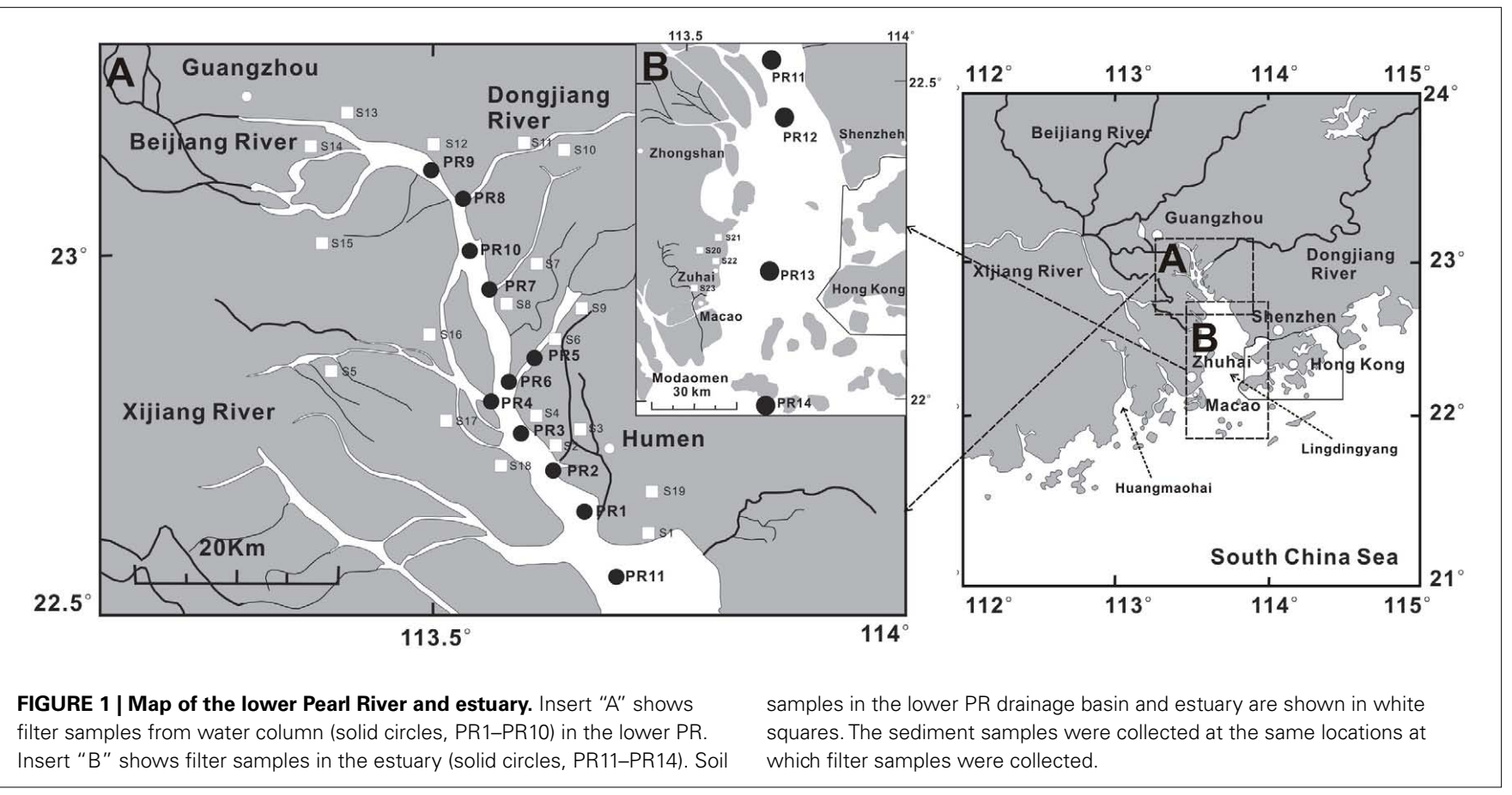

filtering 10-20 L of water. Before water was collected using the submersible pump, a Horiba instrument (Model W-20XD, Kyoto, Japan) was used for in situ determination of water depth, salinity, and temperature.

Surface sediment $(0-10 \mathrm{~cm})$ in the river and estuary was collected using a portable device. The sediment was collected into $50-\mathrm{mL}$ centrifuge tubes and stored in the liquid nitrogen container upon collection (exception was samples for grain size analyses, which were stored under ambient temperature conditions).

Soil samples (from the top 5-10 cm) were collected at 20 locations along the bank of the Beijing tributary and local drainage basin (Figure 1) because this tributary contributes the vast majority of sediments in the estuary. The surface soil samples were collected in 50-mL centrifuge tubes and immediately stored in the liquid nitrogen container. Additional soil material was collected into plastic bags for analysis of grain sizes.

\section{ANALYSES OF ORGANIC CARBON FROM SEDIMENTS AND SOIL}

In the laboratory, aliquots of freeze-dried sediment or soil samples were homogenized for acidification in $10 \% \mathrm{HCl}$, washed with deionized water to remove chloride, and subsequently dried at $80^{\circ} \mathrm{C}$ overnight for analysis of total organic carbon (TOC) using an organic element analyzer EA1110 (Carlo Erba). The carbon isotopes of the TOC were then determined on the GV-Isoprime EA IRMS with a precision of $0.1 \%$ for $\delta^{13} \mathrm{C}$, which is defined as $\left[\left({ }^{13} \mathrm{C} /{ }^{12} \mathrm{C}\right)_{\mathrm{sa}} /\left({ }^{13} \mathrm{C} /{ }^{12} \mathrm{C}\right)_{\text {std }}-1\right] \times 1000$ (where sa, sample, and std, standard).

\section{MEASUREMENTS OF pH, SALINITY, AND GRAIN SIZES OF SEDIMENTS AND SOIL}

The $\mathrm{pH}$ of soil and sediment was determined by drying the samples, which were then pulverized and prepared for each as slurry by adding ultrapure water to the sample powder in a ratio of 1:2.5 $(\mathrm{g} / \mathrm{mL})$. The $\mathrm{pH}$ of the slurry was determined in the upper solution using a $\mathrm{pH}$ meter (Mettler Toledo, USA) after homogenization of the slurry and settling of particles to the bottom of the container.

Pore water salinity was measured using a salinity refractometer (Sino Science and Technology Co., China) after sediment pore water was collected through centrifugation (4000 rpm) and filtered through $0.45-\mu \mathrm{m}$ cellulose acetate membranes.

Grain size analysis followed Xiao et al. (2009). Briefly, about $0.15 \mathrm{~g}$ of sediment or soil material was pretreated with $10-\mathrm{mL}$ of $30 \% \mathrm{H}_{2} \mathrm{O}_{2}$ to remove organic matter and then with $15 \mathrm{~mL}$ of $25 \%$ acetic acid to remove carbonates. $\mathrm{NaOH}$ was used under boiling conditions to remove biogenic silicate. The residue (in $50 \mathrm{~mL}$ solution) was dispersed with $300 \mathrm{mg}$ of $\left(\mathrm{NaPO}_{3}\right)_{6}$ and boiled for $1 \mathrm{~min}$, then cooled down and ultrasonicated for about $3 \mathrm{~min}$ before grain size analysis. The grain size distribution was determined using a laser diffraction size analyzer (Beckman Co., USA), which had a mechanical reproducibility of better than $\pm 1 \%$ for the median diameter.

\section{LIPID EXTRACTION AND LC-MS ANALYSIS}

The freeze-dried sediments and soil were homogenized with a mortar and pestle and frozen filters were cut into pieces before lipid extraction. One of the serial filters or 5-g dry sediment/soil was extracted by sonication ( $10 \mathrm{~min}, 3 \times$ each) with methanol, dichloromethane (DCM)/methanol $(1: 1, \mathrm{v} / \mathrm{v})$, and DCM, respectively, with centrifugation being used after each extraction. The supernatants were pooled, carefully evaporated to dryness under a nitrogen stream at $40^{\circ} \mathrm{C}$, re-dissolved in a small amount of $n$ hexane/DCM (9:1, v/v), and separated into apolar and polar fractions by sequential elution of the total lipids through an activated silica column using $n$-hexane/DCM $(9: 1, \mathrm{v} / \mathrm{v})$ and DCM/methanol $(1: 1, v / v)$, respectively. Half of the polar fraction was condensed, dissolved in $n$-hexane/isopropanol $(99: 1, \mathrm{v} / \mathrm{v})$, and filtered through 
Table 1 | Water depth, temperature (Temp), salinity (Sal.), suspended particulate matter (SPM), and abundances of lipids in the water column.

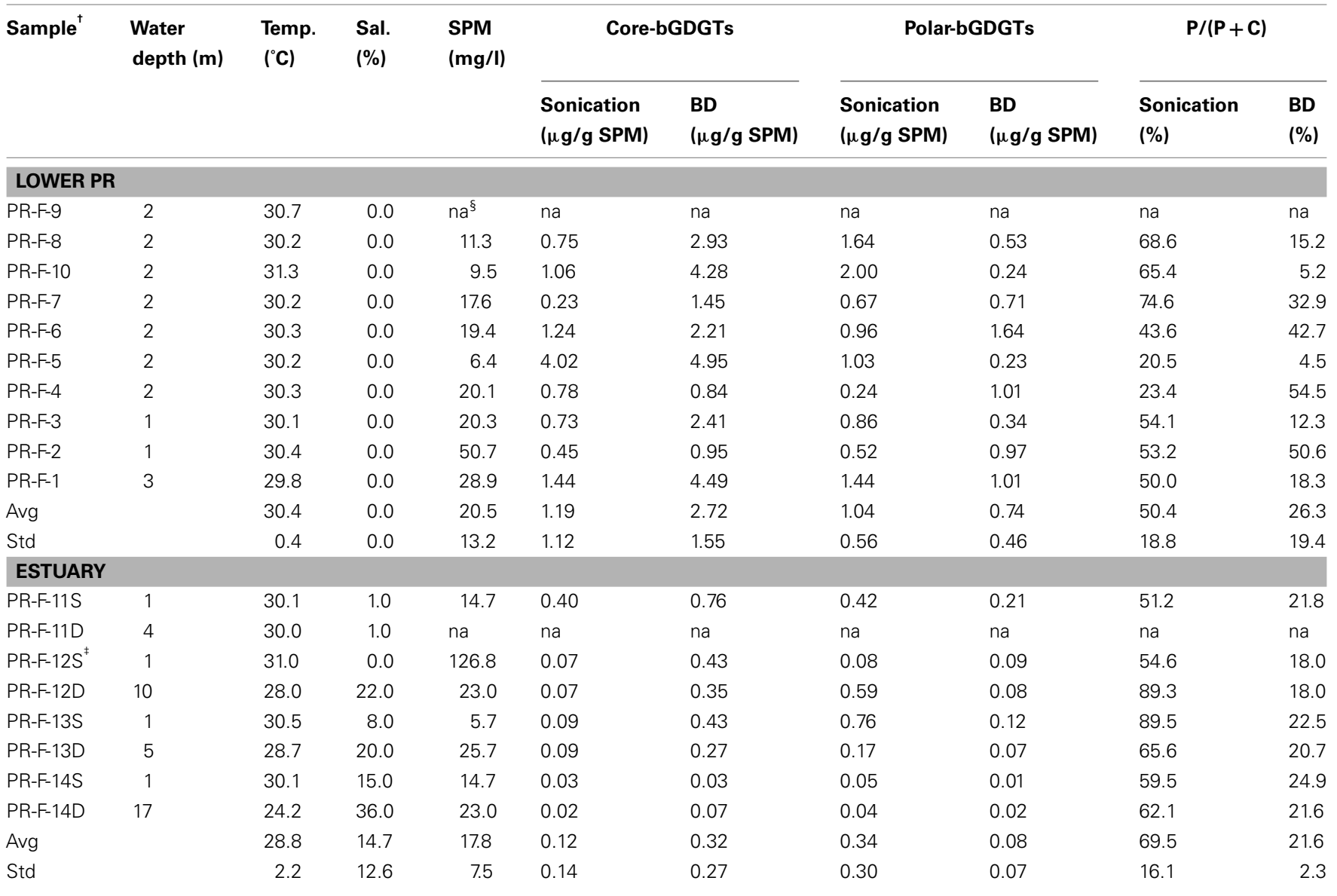

bGDGTs, branched glycerol dialkyl glycerol tetraethers. Core (C)-bGDGTs and polar (P)-bGDGTs are presented for two extraction methods: sonication and Bligh and Dyer (BD).

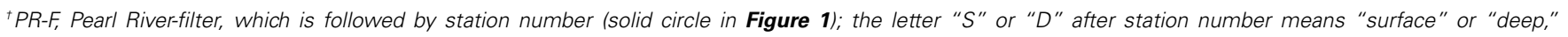
respectively.

${ }^{\ddagger}$ This sample was collected at the front of Xijiang water in the estuary and was excluded from the calculation of average values for the estuary samples.

${ }^{s}$ Not available.

a $0.45-\mu \mathrm{m}$ PTFE filter prior to analysis. The other half of the polar fraction was hydrolyzed $\left(4 \mathrm{~h}, 70^{\circ} \mathrm{C}\right)$ in $5 \% \mathrm{HCl} /$ methanol $(\mathrm{v} / \mathrm{v})$. DCM and MilliQ water were added and the DCM fraction was collected (repeated $4 \times$ ). The DCM fraction was washed $(6 \times)$ with MilliQ water in order to remove acid, and dried under $\mathrm{N}_{2}$. The hydrolyzed fraction was also re-dissolved in $n$-hexane/isopropanol (99:1, v/v) and filtered through $0.45 \mu \mathrm{m}$ PTFE filters prior to analysis on the LC-MS. The difference in LC-MS results between the hydrolyzed and non-hydrolyzed polar fractions is considered to be the IPLs (Huguet et al., 2010b). However, because we did not identify the head groups of the IPLs, the hydrolyzed product may include other fractions not in the form of the IPLs. Thus in this study we consider this difference to be the PL.

A modified Bligh and Dyer extraction procedure (White et al., 1979 ) is preferred for evaluation of intact polar GDGTs from natural environments (Pitcher et al., 2009; Peterse et al., 2010; Tierney et al., 2011; Weijers et al., 2011). This method was also used for extraction of GDGTs from the filter and sediment samples.
The GDGTs were analyzed on an Agilent 1200 liquid chromatography equipped with an automatic injector coupled to QQQ 6460 MS and Mass Hunter LC-MS manager software using a procedure modified from Hopmans et al. (2004) and Schouten et al. (2007). Separation of peaks was achieved using a Prevail Cyano column $(2.1 \mathrm{~mm} \times 150 \mathrm{~mm}, 3 \mu \mathrm{m}$; Alltech Deerifled, IL, USA) maintained at a temperature of $40^{\circ} \mathrm{C}$. Injection volume was $5 \mu \mathrm{L}$. GDGTs were first eluted isocratically with $90 \%$ A and $10 \%$ $\mathrm{B}$ for $5 \mathrm{~min}$, followed by a linear gradient to $18 \% \mathrm{~B}$ in $45 \mathrm{~min}$. Solvent was held for $10 \mathrm{~min}$ in $100 \% \mathrm{~B}$ and was then allowed to re-equilibrate in a mixture of $\mathrm{A}: \mathrm{B}(9: 1, \mathrm{v} / \mathrm{v})$ for $10 \mathrm{~min}$. A represents $n$-hexane and B is a mixture of $90 \% n$-hexane and $10 \%$ isopropanol.

Detection of GDGTs was performed using the Agilent 6460 triple-quadrupole mass spectrometer (MS) with an atmospheric pressure chemical ionization (APCI) ion source. The scanning type used was single ion monitoring mode of protonated molecules. The conditions for APCI/MS were as follows: nebulizer pressure 
40 psi, vaporizer temperature $350^{\circ} \mathrm{C}$, drying gas $\left(\mathrm{N}_{2}\right)$ flow $5 \mathrm{~L} / \mathrm{min}$ and temperature $250^{\circ} \mathrm{C}$, capillary voltage $3 \mathrm{kV}$, and corona $4 \mu \mathrm{A}$. All samples were quantified by adding a known amount of an internal $\mathrm{C}_{46}$ standard with a detection limit of $0.8 \mathrm{pg}$.

\section{DEFINITION OF THE bGDGT PROXIES}

The following formulas were used for calculation of the BIT (Hopmans et al., 2004), MBT and CBT (Weijers et al., 2007a) indices:

$$
\begin{aligned}
\mathrm{BIT} & =\frac{\mathrm{I}+\mathrm{II}+\mathrm{III}}{\mathrm{I}+\mathrm{II}+\mathrm{III}+\text { Cren }} \\
\mathrm{MBT} & =\frac{\mathrm{I}+\mathrm{Ib}+\mathrm{Ic}}{\mathrm{I}+\mathrm{Ib}+\mathrm{Ic}+\mathrm{II}+\mathrm{IIb}+\mathrm{IIc}+\mathrm{III}+\mathrm{IIIb}+\mathrm{IIIc}} \\
\mathrm{CBT} & =-\log \frac{\mathrm{Ib}+\mathrm{IIb}}{\mathrm{I}+\mathrm{II}}
\end{aligned}
$$

The structures of bGDGTs and crenarchaeol (Cren) are presented in Appendix.

Mean air temperatures and soil or sediment $\mathrm{pH}$ derived from CBT and MBT were calculated using Weijers et al. (2007a):

$$
\begin{aligned}
\mathrm{T}_{\mathrm{MBT} / \mathrm{CBT}} & =\left(\mathrm{MBT}-0.122-0.187^{*} \mathrm{CBT}\right) / 0.02 \\
\mathrm{pH}_{\mathrm{CBT}} & =(3.33-\mathrm{CBT}) / 0.38
\end{aligned}
$$

\section{RESULTS AND DISCUSSION PRODUCTION OF bGDGTS IN WATER COLUMN AND SURFACE SEDIMENTS \\ Water column}

Concentrations of P-bGDGTs obtained from the sonication and Bligh and Dyer methods showed large variations and an overall decrease from the lower PR to the estuary (Figure 2A). When using the sonication method, P-bGDGTs had a range of $0.24-2.0 \mu \mathrm{g} / \mathrm{g}$ SPM (average $=1.04 \pm 0.56 \mu \mathrm{g} / \mathrm{g} \mathrm{SPM}, n=9$ ) in the lower PR and a range of $0.05-0.76 \mu \mathrm{g} / \mathrm{g}$ SPM (average $=0.34 \pm 0.30 \mu \mathrm{g} / \mathrm{g}$ SPM, $n=7$ ) in the estuary (Figures 3A,B; Table 1). The Bligh and Dyer method yielded lower concentrations of P-bGDGTs, which had a range of $0.23-1.64 \mu \mathrm{g} / \mathrm{g}$ SPM (average $=0.75 \pm 0.46 \mu \mathrm{g} / \mathrm{g}$ SPM, $n=9$ ) in the lower PR and a range of 0.01-0.21 (average $=0.08 \pm 0.07 \mu \mathrm{g} / \mathrm{g} \mathrm{SPM}, n=7$ ) in the estuary (Figures 3A,B; Table 1). Overall, larger variations in P-bGDGTs are associated with the sonication method than with the Bligh and Dyer for the water column samples (Figures 3A,B).

\section{Sediments}

Concentrations of P-bGDGTs in sediments had large variations in the lower PR (Figure 2B). In the lower PR, the sonication method yielded P-bGDGTs concentrations in a range of 2.2$52.7 \mathrm{ng} / \mathrm{g}$ sediment $(0.2-2.6 \mu \mathrm{g} / \mathrm{g}$ TOC) with an average value of $17.1 \pm 14.9 \mathrm{ng} / \mathrm{g}$ sediment $(1.1 \pm 0.7 \mu \mathrm{g} / \mathrm{g}$ TOC, $n=9$; Figure $3 \mathrm{C}$; Table 2); the Bligh and Dyer method yielded P-bGDGTs in a range of $6.4-46.7 \mathrm{ng} / \mathrm{g}$ sediment $(0.2-4.4 \mu \mathrm{g} / \mathrm{g}$ TOC) with an average value of $33.6 \pm 7.9 \mathrm{ng} / \mathrm{g}$ sediment $(2.6 \pm 1.2 \mu \mathrm{g} / \mathrm{g}$ TOC; Figure 3C; Table 2). In the estuary, the two methods yielded similar concentrations of P-bGDGTs at each station (Table 2), which had an average value of $15.4 \pm 8.9 \mathrm{ng} / \mathrm{g}$ sediment $(1.8 \pm 0.7 \mu \mathrm{g} / \mathrm{g}$ TOC; $n=3$ ) from the sonication method and $18.5 \pm 8.7 \mathrm{ng} / \mathrm{g}$

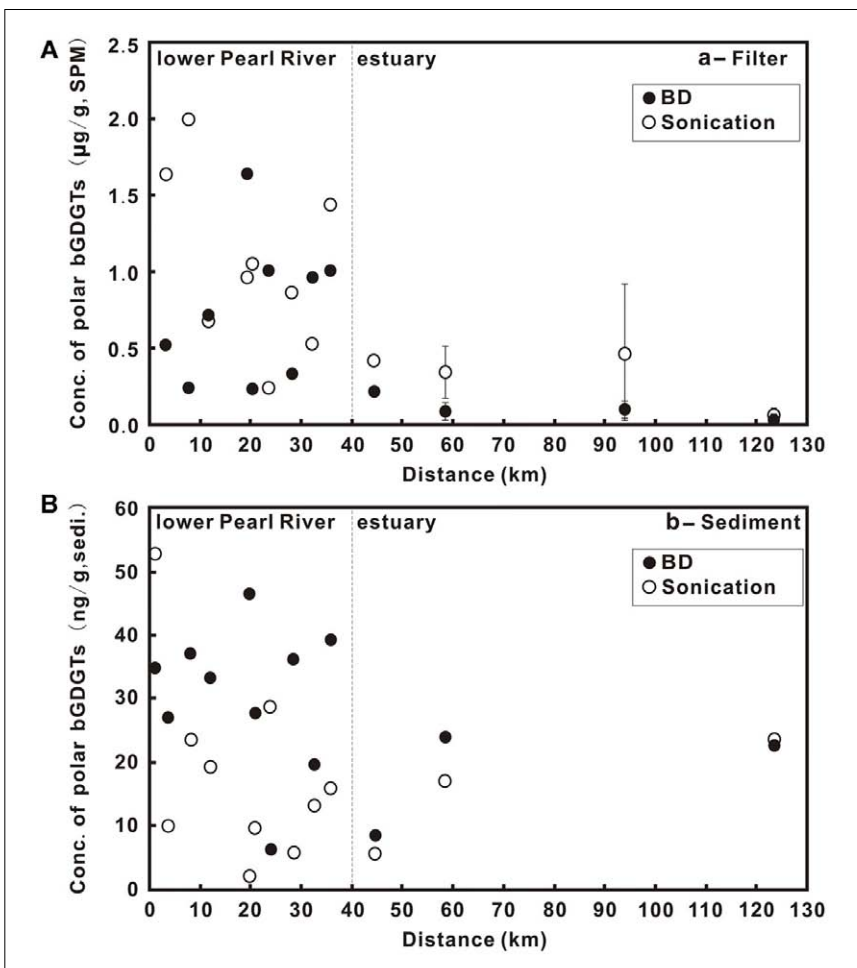

FIGURE 2 | Core (C)- and polar(P)-lipids (L) of bGDGTs in the water column (A) and sediments $(B)$ from the lower Pearl River to the estuary. Zero distance is arbitrarily set at PR-9 in Figure $\mathbf{1}$ and increasing distance is toward the estuary. The error bars in (A) represent SD of the average values between the surface water- and the bottom water samples in the estuary.

sediment $(2.2 \pm 0.3 \mu \mathrm{g} / \mathrm{g}$ TOC) from the Bligh and Dyer method (Figure 3D).

The difference in P-bGDGTs concentration between the two methods was further evaluated using the student $t$-test, which gave $P$-values $>0.05$ for all water column samples from the lower $\mathrm{PR}$ and the estuary. In the sediments, however, the $P$-value was $<0.05$ in the lower PR and $>0.05$ in the estuary. This indicates that these two methods statistically yielded similar concentrations of P-bGDGTs in the water column; whereas in sediments the Bligh and Dyer method yielded significantly higher P-bGDGTs in the lower PR than the sonication method (Table 2).

When normalized to total bGDGTs (P-bGDGTs + C-bGDGTs), the P-bGDGTs in the water column averaged $50.4 \pm 18.8 \%$ in the lower PR and $69.5 \pm 16.1 \%$ in the estuary, by the sonication method (Table 1). On the other hand, the relative abundance of P-bGDGTs from the Bligh and Dyer method was much lower, averaging $21.6 \%$ for both the lower PR and the estuary (Table 1), which were both statistically $(P<0.05)$ lower than the sonication method. This lower ratio was apparently caused by the greater concentrations of C-bGDGTs produced by the Bligh and Dyer method than the sonication method (Figures 3A,B). In the sediments, the sonication method yielded $6.9 \pm 3.8 \%$ of P-bGDGTs in total lipids in the lower PR, which was significantly $(P<0.05)$ lower than the Bligh and Dyer method (14.2 $\pm 8.6 \%$; Table 2$)$, mostly due to the higher concentrations of the P-bGDGTs by the latter method (avg. $33.6 \mathrm{ng} / \mathrm{g}$ vs. $17.1 \mathrm{ng} / \mathrm{g}$; Table 2 ). 

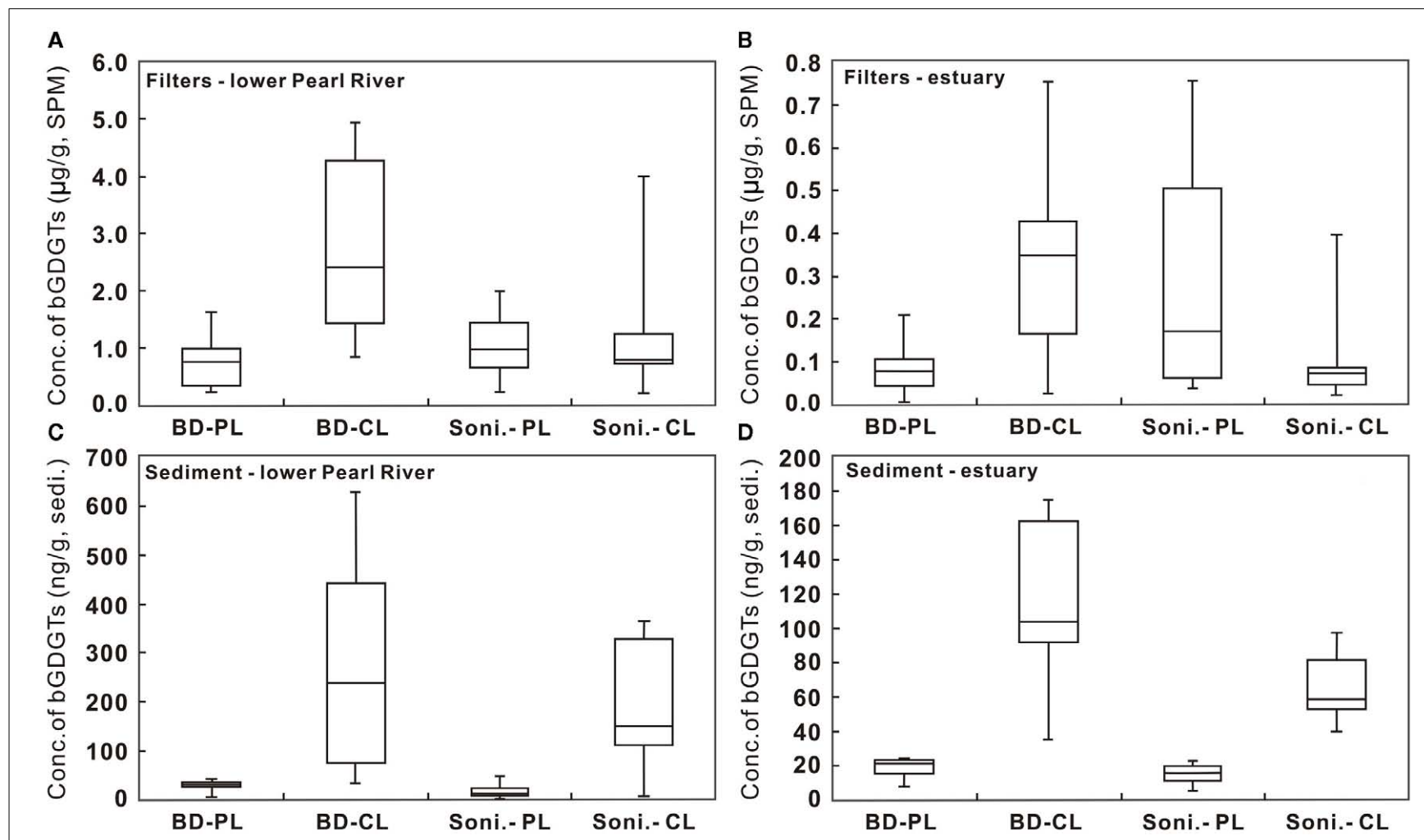

FIGURE 3 | Comparison of concentrations of C- and P-bGDGTs extracted using the sonication (Soni) and Bligh and Dyer (BD) methods for water column (A,B) and sediment (C,D) samples from the lower Pearl River and estuary. $C L$, core lipids; $P L$, polar lipids.

The soil samples were analyzed using the sonication method only, which yielded P-bGDGTs having a range of $0.5-146.2 \mathrm{ng} / \mathrm{g}$ in soil (0.1-12.8 $\mu \mathrm{g} / \mathrm{g}$ TOC; Table 3 ). The relative abundance of PbGDGTs in total lipids had a range of $1.4-31.0 \%$, with an average value of $7.8 \pm 7.1 \%(n=20)$, which is close to the average value of P-bGDGTs in the sediments of the lower PR (Table 2).

One caveat associated with the sonication method is that the PLs may be matrix-bonded rather than originating from intact microbial cells (Huguet et al., 2010a). This might be the case for the water column filters, which tended to yield higher concentrations of P-bGDGTs by the sonication method than by the Bligh and Dyer method (Table 1), even though the student $t$-test did not show a significant difference between the two methods for each sample. On the other hand, concentrations of P-bGDGTs from the lower PR sediments were significantly lower when determined by the sonication method than by the Bligh and Dyer, which is inconsistent with the excess extraction of PLs that are matrix-bonded when sonication is used (Huguet et al., 2010a). This suggests that the yield of matrix-bonded PLs may be affected by the structure and composition of the solids with which the lipids are bonded. The difference may also be caused by specific procedures used in each lab or by other unknown variables. The factors causing the differences in the yield of P-bGDGTs in different methods are not well understood.

Only a few studies have reported the abundances of P-bGDGTs in soil and peat bog environments and used them as biomarkers of living organisms (Liu et al., 2010; Peterse et al., 2010; Weijers et al., 2011). In this study, the P-bGDGTs in soil and sediments are in the same range as reported by Peterse et al. (2010) and Weijers et al. (2011). Early studies have showed that C-bGDGTs are widespread in soil and peat bogs (e.g., Weijers et al., 2006a, 2007a) and bGDGTs observed in marine systems are mostly derived from the terrestrial environments (Hopmans et al., 2004; Weijers et al., $2006 \mathrm{a}, \mathrm{b})$. However, it has been shown that the in situ production of bGDGTs appeared to contribute to some of the observed bGDGTs in a fjord environment where soil organic matter was low (Peterse et al., 2009). Most recently, in situ production of bGDGTs in the oxic East China Sea shelf was also reported (Zhu et al., 2011b). Both studies made the conclusions using measurements of core lipids. The ubiquitous presence of P-bGDGTs from filter and sediment samples in the Pearl River and estuary further supports those observations and indicates that living organisms producing P-bGDGTs may be present in these environments. However, the source of bGDGTs in the oxic water column is unknown. One possibility may be the production by aerobic or facultative aerobic organisms in the oxic water; the other possibility may be production by anaerobic organisms that reside in suspended particles containing micro-anoxic environments.

\section{CORRELATIONS BETWEEN ABUNDANCES OF bGDGTS AND pH OR TOC IN SEDIMENTS}

bGDGTs were normalized to the clay fraction when compared with TOC because the abundance of bGDGTs tended to be higher with increasing clay content (data not shown). In the sediments, 


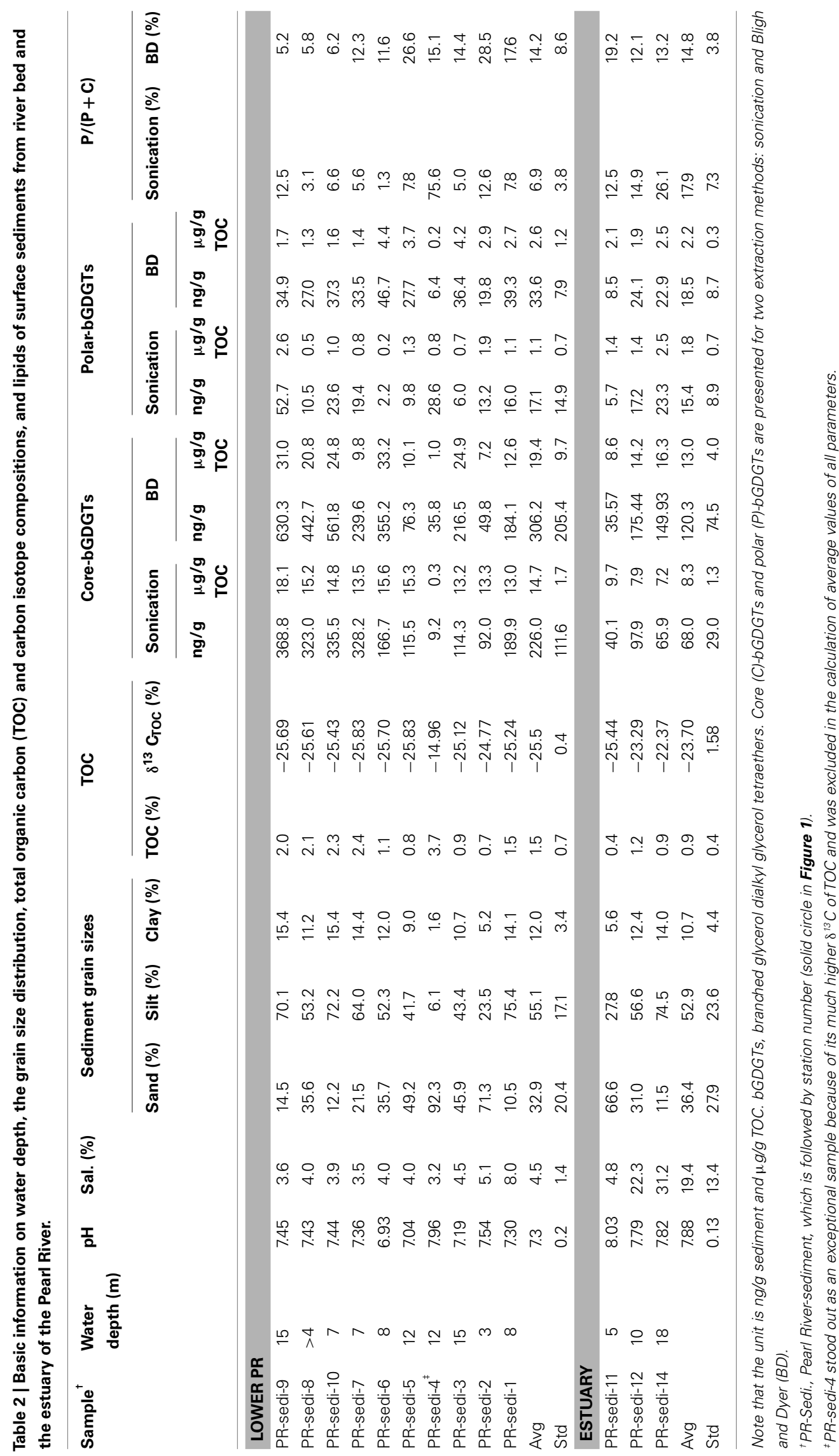


Table 3 | Basic information on pH, grain size distribution, total organic carbon (TOC) and carbon isotope compositions, and lipids of surface soils in the lower Pearl River drainage basin.

\begin{tabular}{|c|c|c|c|c|c|c|c|c|c|c|c|}
\hline Sample $^{\dagger}$ & $\mathrm{pH}$ & \multicolumn{3}{|c|}{ Soil grain distribution } & \multicolumn{2}{|c|}{ TOC } & \multicolumn{2}{|c|}{ Core-bGDGTs } & \multicolumn{2}{|c|}{ Polar-bGDGTS } & $P /(P+C)(\%)$ \\
\hline PR-soil-14 & 6.53 & 9.3 & 76.8 & 13.9 & 0.93 & -22.92 & 288.5 & 31.07 & 7.9 & 0.85 & 2.7 \\
\hline PR-soil-12 & 8.03 & 32.9 & 57.2 & 10.0 & 0.21 & -24.62 & 80.1 & 38.30 & 2.7 & 1.30 & 3.3 \\
\hline PR-soil-11 & 7.54 & 34.5 & 59.1 & 6.3 & 0.26 & -22.65 & 9.5 & 3.67 & 0.5 & 0.21 & 5.3 \\
\hline PR-soil-15 & 7.58 & 65.7 & 30.2 & 4.1 & 1.00 & -23.52 & 400.5 & 40.07 & 33.5 & 3.36 & 7.7 \\
\hline PR-soil-7 & 7.76 & 31.3 & 58.3 & 10.4 & 2.20 & -23.41 & 18.7 & 0.85 & 1.7 & 0.08 & 8.5 \\
\hline PR-soil-8 & 4.54 & 11.5 & 72.7 & 15.8 & 0.73 & -22.55 & 70.3 & 9.64 & 5.6 & 0.77 & 7.4 \\
\hline PR-soil-9 & 8.18 & 30.2 & 61.6 & 8.3 & 1.77 & -22.95 & 285.5 & 16.17 & 5.0 & 0.28 & 1.7 \\
\hline PR-soil-16 & 7.72 & 44.6 & 46.0 & 9.4 & 0.86 & -21.37 & 134.0 & 15.58 & 3.3 & 0.39 & 2.4 \\
\hline PR-soil-6 & 4.30 & 32.9 & 54.9 & 12.1 & 0.33 & -22.95 & 122.4 & 36.86 & 9.7 & 2.91 & 7.3 \\
\hline PR-soil-3 & 5.86 & 57.9 & 37.4 & 4.8 & 1.21 & -24.93 & 358.9 & 29.78 & 62.7 & 5.20 & 14.9 \\
\hline PR-soil-2 & 6.28 & 7.6 & 75.1 & 17.3 & 0.85 & -22.61 & 176.5 & 20.83 & 12.1 & 1.43 & 6.4 \\
\hline PR-soil-18 & 4.33 & 39.6 & 50.8 & 9.6 & 1.17 & -25.42 & 479.3 & 40.99 & 22.4 & 1.91 & 4.5 \\
\hline PR-soil-19 & 6.64 & 70.6 & 25.3 & 4.1 & 0.47 & -20.20 & 79.3 & 17.04 & 35.6 & 7.64 & 31.0 \\
\hline PR-soil-1 & 5.22 & 42.9 & 57.1 & 6.9 & 0.88 & -26.99 & 162.1 & 18.33 & 16.9 & 1.91 & 9.4 \\
\hline PR-soil-20 & 4.49 & 42.3 & 50.1 & 7.6 & 0.32 & -26.74 & 124.1 & 38.80 & 3.7 & 1.15 & 2.9 \\
\hline Avg & 6.6 & 39.3 & 52.1 & 9.0 & 0.8 & -23.4 & 202.1 & 27.5 & 19.5 & 2.3 & 7.8 \\
\hline Std & 1.4 & 21.9 & 18.1 & 4.1 & 0.5 & 1.8 & 165.5 & 18.4 & 33.6 & 3.1 & 7.1 \\
\hline
\end{tabular}

bGDGTs, branched glycerol dialkyl glycerol tetraethers; P, polar-bGDGTs; $C$, core-bGDGTs.

${ }^{+}$Sample numbers are white solid squares in Figure 1.

the abundances of C-bGDGTs from either the sonication or Bligh and Dyer increased significantly with TOC for concentration up to $2.5 \%$ (Figure 4). The P-bGDGTs from both methods remained low $(<5 \%)$ with increasing TOC; one exception was the sample having the highest TOC, which had much higher P-bGDGT abundance from the sonication extraction than from the Bligh and Dyer method (Table 2). In the soil samples, no significant correlations existed between C-bGDGTs and TOC or between P-bGDGTs and TOC from both methods (data not shown). The results suggest that the abundance of C-bGDGTs was affected by the availability of TOC in the sediments but not in soils within the study area; and that the abundance of P-bGDGTs was insensitive to changes in TOC.

The correlation between clay-normalized bGDGTs and $\mathrm{pH}$ had a maximum around $\mathrm{pH} 7.4$ (Figure $4 \mathbf{B}$ ). When normalized to the content of TOC, a more significant negative correlation was observed for bGDGTs obtained from the sonication method than the Bligh and Dyer method (Figure 4C). Similarly, in soil samples, no correlation existed between $\mathrm{pH}$ and abundance of either $\mathrm{C}$ - or P-bGDGTs normalized to TOC, or when normalized to soil clay fractions (data not shown).

The pH-bGDGT correlation for the sediment samples in this study is consistent with observations from Weijers et al. (2007a) in a global survey of soil bGDGTs. A long-term soil manipulation also shows that soil $\mathrm{pH}$ is the only varying control on the abundance and distribution of branched GDGTs (Peterse et al., 2010). The lack of correlations between bGDGTs and $\mathrm{pH}$ in the PR soil, however, suggests that other variables (other than TOC) may play a role in controlling the abundance of bGDGTs in this region.

\section{CHANGES IN bGDGTS-DERIVED PROXIES FROM THE LOWER PEARL RIVER TO ESTUARY $B I T, M B T$, and CBT in the water column}

The BIT values in the water column decreased in a nonlinear pattern for both the $\mathrm{C}$ - and P-bGDGTs in the lower PR (Figures $\mathbf{5 A}, \mathbf{A}^{\prime}$ ). In the estuary, BIT values (for either C- or PbGDGTs) decreased sharply from above 0.81 at station 11 to less than 0.1 at station 14 in either method (Figures $\mathbf{5 A}, \mathbf{A}^{\prime}$ ). The MBT values for C-bGDGTs were relatively constant and around 0.6 from the lower PR and estuary for the two methods (Figure 5B). The MBT values for P-bGDGTs obtained from the Bligh and Dyer method was also relatively constant and around 0.6; whereas, the values obtained from the sonication method showed much larger variations (Figure 5 $\mathbf{B}^{\prime}$ ). The CBT values showed larger variations for both C- and P-bGDGTs in the lower PR than in the estuary, with the former varying between 0.6 and 1.2 and the latter between 0.4 and 1.4 in either method (Figures $5 \mathbf{C}, \mathbf{C}^{\prime}$ ). 


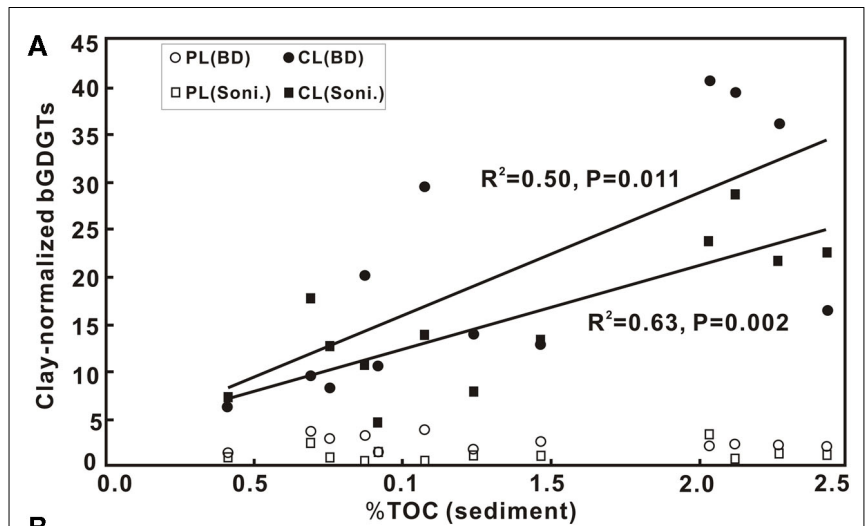

B
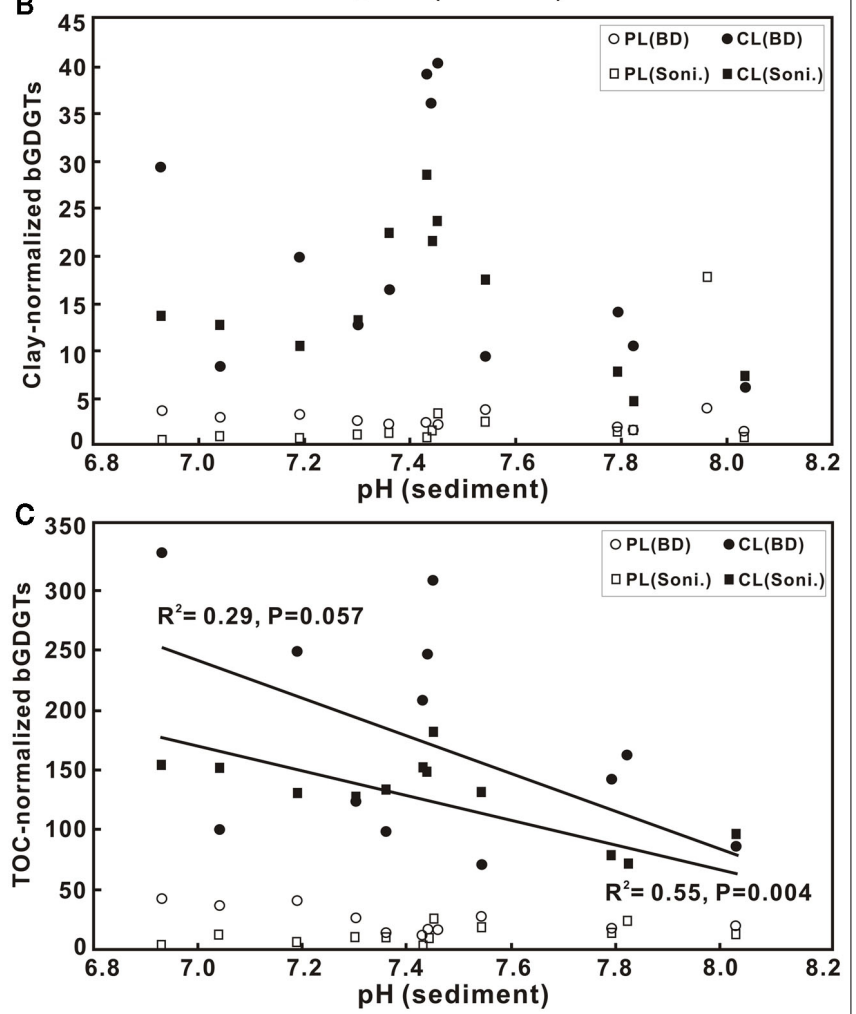

FIGURE 4 | Scatter diagrams of TOC in sediments vs. clay-normalized bGDGTs in $\mathrm{ng} / \mathrm{g} \times 10^{2}(\mathrm{~A})$, and $\mathrm{pH}$ vs. clay-normalized bGDGTs in $\mathrm{ng} / \mathrm{g} \times 10^{2}$ (B) and TOC-normalized bGDGTs in $\mathrm{ng} / \mathrm{g} \times 10^{2}$ (C) for both sonication (Soni) and Bligh and Dyer (BD) methods. $C L$, core lipids; $P L$ polar lipids.

\section{$B I T, M B T$, and $C B T$ in the sediments}

Variations in BIT, MBT, and CBT showed very little difference between the two methods for the C-bGDGTs (Figures 6A-C). For the P-bGDGTs, however, the proxies based on the sonication method varied more than those based on the Bligh and Dyer method (Figures $\mathbf{6} \mathbf{A}^{\prime}-\mathbf{C}^{\prime}$ ). These results along with those from the water column suggest that proxies derived from C-bGDGTs are not affected by different extraction methods; whereas, proxies derived from P-bGDGTs appeared to be more stable based on the Bligh and Dyer method than the sonication method.
IMPLICATIONS FOR CBT- AND MBT-DERIVED pH AND TEMPERATURES CBT-derived $\mathrm{pH}$

The CBT proxy is known to correlate with the $\mathrm{pH}$ of the environment from which the bGDGTs are derived (e.g., Weijers et al., 2007a; Peterse et al., 2010). In this study, a student $t$ test was performed to compare calculated $\mathrm{pH}$ values from $\mathrm{C}$ bGDGTs and P-bGDGTs (extracted using either sonication or Bligh and Dyer method) and compare them with the measured $\mathrm{pH}$ values (Figure 7 ). In the sonication method, the CBT-derived $\mathrm{pH}$ values of soil samples showed large variations and were statistically indifferent between the C- and P-bGDGTs, with their average $\mathrm{pH}$ values similar to the measured average soil $\mathrm{pH}$ value $(6.56 \pm 1.39, n=20$; Figure 7$)$. These results suggest that CBT-derived $\mathrm{pH}$ values statistically reflect the in situ soil $\mathrm{pH}$.

The CBT-derived $\mathrm{pH}$ values of the sediments in both the sonication and Bligh and Dyer methods varied between the average measured $\mathrm{pH}$ values of the sediments $(7.48 \pm 0.34)$ and soil $(6.56 \pm 1.39$; Figure 7$)$. For the sonication method, the student $t$ test showed that the calculated $\mathrm{pH}$ values from either C-bGDGTs or P-bGDGTs (Table A1 in Appendix) were significantly different from the measured individual sediment $\mathrm{pH}$ values (Table 2 ). However, no significant differences existed between sediment Cor P-bGDGT-derived $\mathrm{pH}$ values and measured soil $\mathrm{pH}$ values (Table 3), possibly due to the large variation of the measured soil $\mathrm{pH}$ (Figure 7). Nevertheless, these results may suggest that the sonication-derived CBT proxy reflects soil $\mathrm{pH}$ and not the in situ sediment $\mathrm{pH}$.

For the Bligh and Dyer method, the student $t$-test showed that the $\mathrm{pH}$ values from the C-bGDGTs and P-bGDGTs were significantly different (Table A2 in Appendix), with the latter close to the average measured sediment $\mathrm{pH}$ value (Figure 7) and significantly different from the average measured soil $\mathrm{pH}(P<0.05)$. On the other hand, no significant difference existed in the average $\mathrm{pH}$ value between sediment C-bGDGTs and soil.

These results indicate that using the sonication method both $\mathrm{C}$ - and P-bGDGTs from the sediments likely reflect soil $\mathrm{pH}$, whereas using the Bligh and Dyer method the C-bGDGTs likely reflect terrestrial soil $\mathrm{pH}$ but the P-bGDGTs may reflect in situ sediment $\mathrm{pH}$.

\section{MBT/CBT-derived temperatures}

The MBT-CBT proxy has been increasingly used to reconstruct past annual MAT in continental margins or shelves (Weijers et al., 2007b,c; Schouten et al., 2008; Donders et al., 2009; Bendle et al., 2010; Fawcett et al., 2011; Peterse et al., 2011). While the annual MAT in the lower PR basin is about $22^{\circ} \mathrm{C}$ (Zhang et al., 2008), in July when our cruise was carried out, a mean monthly temperature of $30^{\circ} \mathrm{C}$ was recorded near the city of Guangzhou (Liu et al., 2007). The measured water temperature averaged $30.4 \pm 0.4^{\circ} \mathrm{C}$ in the lower PR and $28.8 \pm 2.2^{\circ} \mathrm{C}$ in the estuary with the bottom water about $2.0-4.0^{\circ} \mathrm{C}$ lower than the surface water (Table 1). Statistically, the water temperature was not significantly different between the lower PR and the estuary and the average was $29.8 \pm 1.6^{\circ} \mathrm{C}$ between the two environments.

Temperatures calculated according to Weijers et al. (2007a) resulted in higher values for C-bGDGTs than P-bGDGTs for 
A

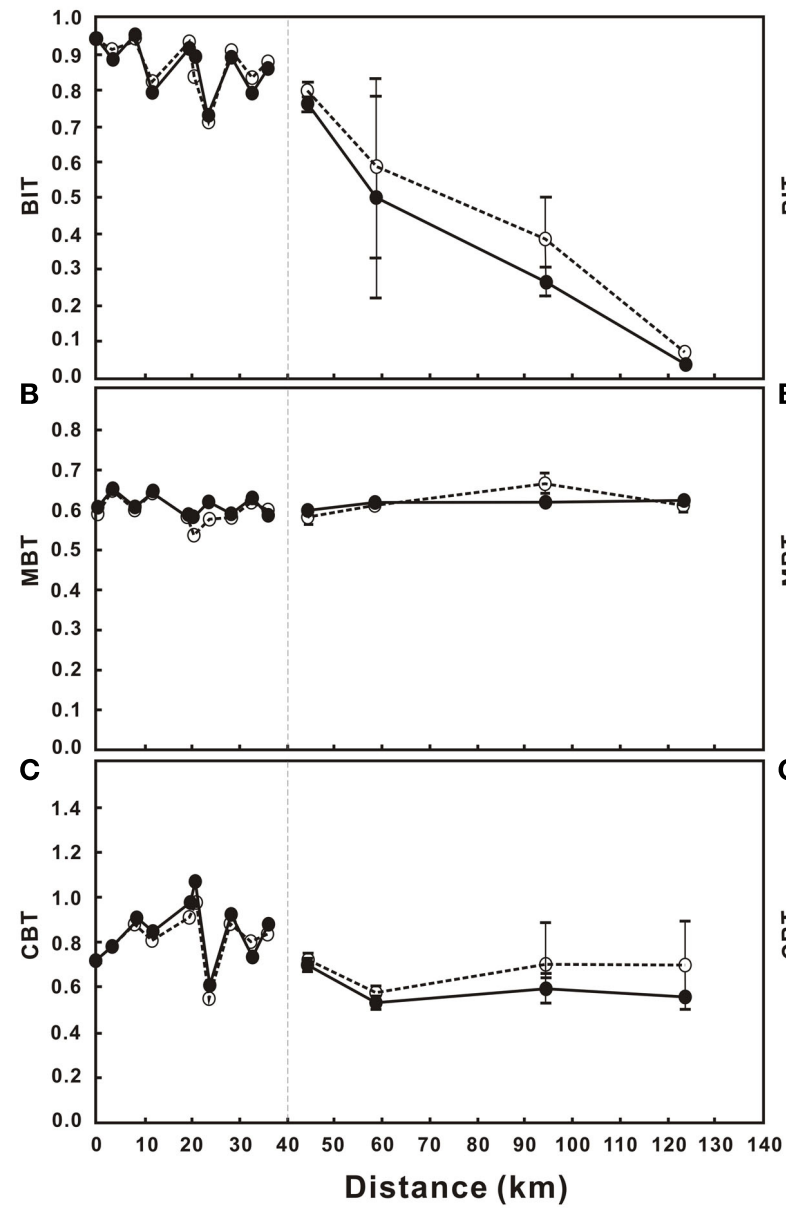

$A^{\prime}$

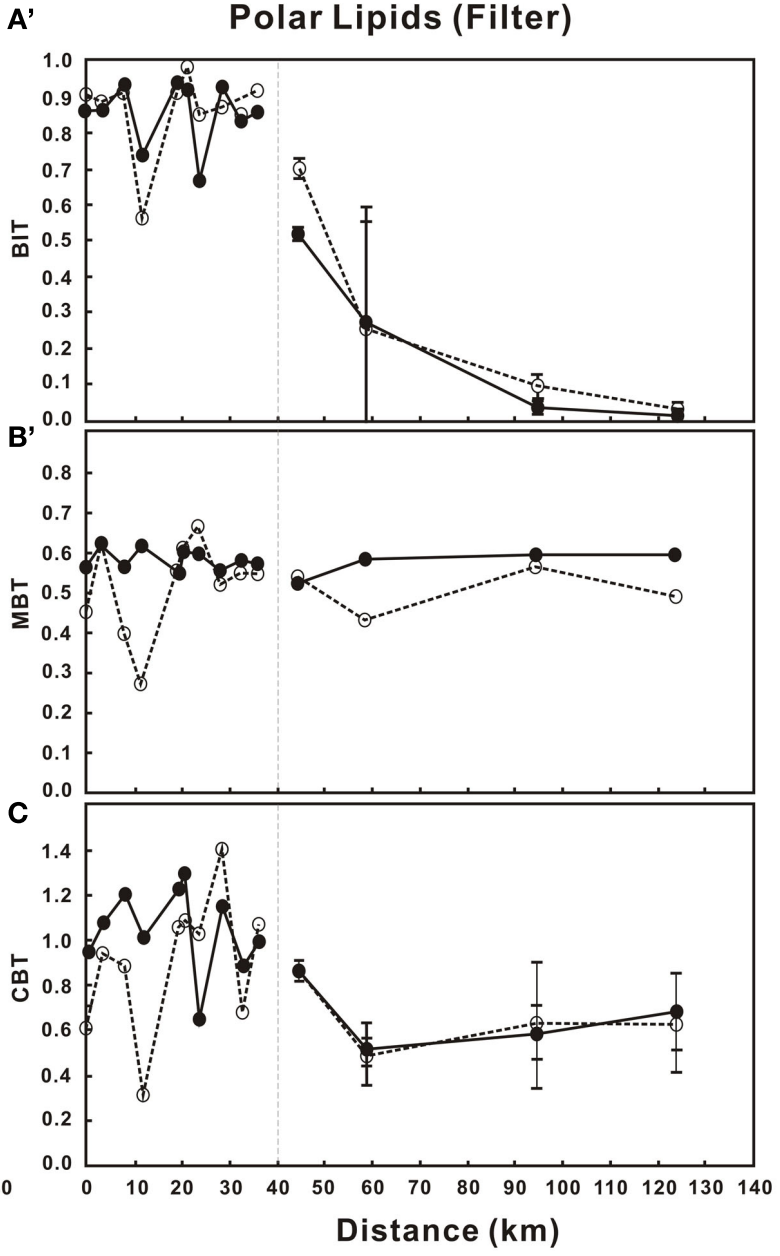

-..--..-Sonication
FIGURE 5 | Changes in BIT, MBT, and CBT in the water column from lower Pearl River to the estuary for C-bGDGTs (A-C) and P-bGDGTs $\left(A^{\prime}-C^{\prime}\right)$ for the sonication and Bligh and Dyer (BD) methods. Zero distance is arbitrarily set at PR-9 in Figure $\mathbf{1}$ and increasing distance is toward the estuary. The error bars in each panel represent SD of the average values between the surface water- and the bottom water samples in the estuary. all samples (Tables A1-A3 in Appendix). In soil samples, the calculated temperatures had a range of $18.7-28.1^{\circ} \mathrm{C}$ (average $24.3 \pm 3.1^{\circ} \mathrm{C}, n=20$ ) for C-bGDGTs and a range of -2.9 to $29.2^{\circ} \mathrm{C}$ (average $13.8 \pm 1.1^{\circ} \mathrm{C}$ ) for P-bGDGTs (Figure 8). For the sediment samples, the calculated temperatures had similar ranges for C-bGDGTs using either the sonication (Table A1 in Appendix) or Bligh and Dyer (Table A2 in Appendix) method, with the former having an average temperature of $21.1 \pm 1.0^{\circ} \mathrm{C}$ and the latter $20.7 \pm 1.1^{\circ} \mathrm{C}$ (Figure 8). The P-bGDGTs again resulted in lower values for either the sonication or Bligh and Dyer method, with the former showing considerably greater variability than the latter (Figure 8).

The calculated temperatures from the C-bGDGTs were all closer to the mean annual air temperature $\left(22^{\circ} \mathrm{C}\right)$ of the region than to the monthly MAT in July when the samples were taken (Figure 8). The bGDGTs from sediments did not seem to register any temperature signatures from the water column (average
$29.8 \pm 1.6^{\circ} \mathrm{C}$; Figure 8), which suggests that water column production of bGDGTs in the lower PR and estuary did not have a significant impact on the sediment C-bGDGTs. These results also indicate that temperatures calculated from the C-bGDGTs were not affected by different extraction methods, whereas those from the P-bGDGTs could be severely affected. The relatively higher temperatures from the C-bGDGTs calculated for the soil may indicate a seasonal bias favoring the period of the summer when soil samples were collected. However, Weijers et al. (2011) showed no seasonal variation in MBT/CBT-derived temperatures in mid-latitude soils. On the other hand, even if a slight seasonal preference of bGDGT production does exists in soil, it may be difficult to separate from natural variability caused by soil heterogeneity (Weijers et al., 2011). The temporal variation in $\mathrm{MBT} / \mathrm{CBT}$ temperatures in the lower PR requires further evaluation by sampling in different seasons before a conclusion can be drawn. 

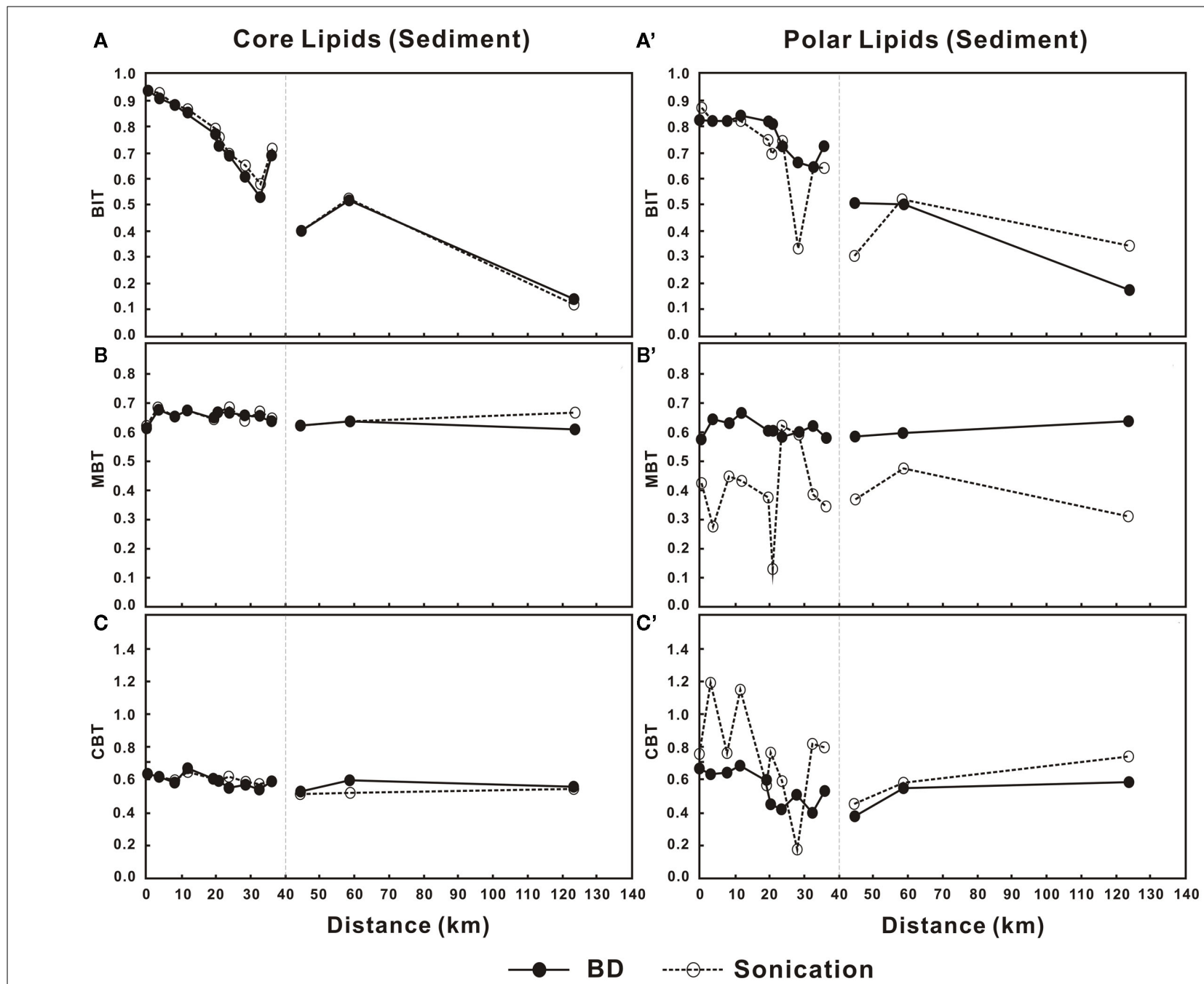

-..--..- Sonication

FIGURE 6 | Changes in BIT, MBT, and CBT in the sediments from lower Pearl River to the estuary for C-bGDGTs (A-C) and P-bGDGTs $\left(A^{\prime}-C^{\prime}\right)$ for

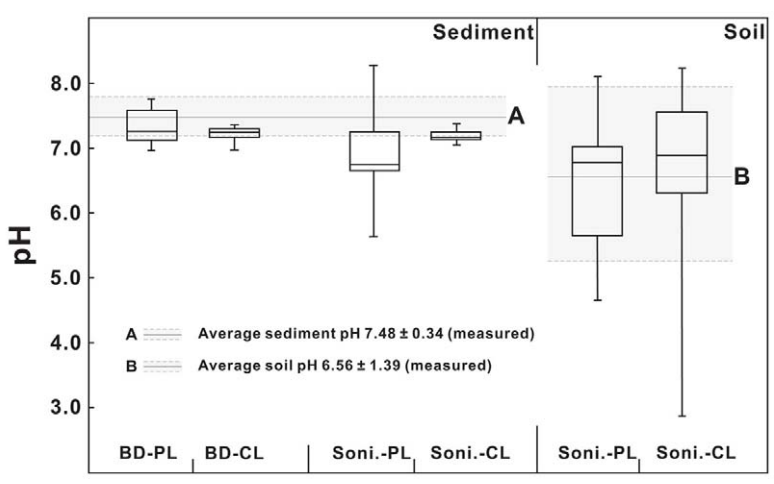

FIGURE 7 | Comparison of CBT-derived $\mathrm{pH}$ to measured $\mathrm{pH}$ values of soil and sediments for the sonication (Soni) and Bligh and Dyer (BD) methods. $C L$, core lipids; $P L$, polar lipids. the sonication and Bligh and Dyer (BD) methods. Zero distance is arbitrarily set at PR-9 in Figure $\mathbf{1}$ and increasing distance is toward the estuary.

\section{CONCLUSION}

Increasing evidence indicates that bGDGTs can be produced in situ in aquatic environments other than the soil, which has traditionally been considered to be the major source of these compounds. In this study, two extraction methods (sonication and Bligh and Dyer) yield substantial amounts of P-bGDGTs in the water column and sediments, suggesting in situ production of bGDGTs in the lower Pearl River and estuary. The BIT values decrease systematically from the lower Pearl River to the estuary and the pattern is not influenced by the method of extraction. The bGDGTs-derived temperature and $\mathrm{pH}$ proxies also are not affected by extraction method when calculations are performed using the C-bGDGTs. In such cases, the $\mathrm{pH}_{\mathrm{CBT}}$ values in sediments are not statistically different from those of the surrounding soil, indicating that the C-bGDGTs are predominantly derived from the terrestrial environment. Similarly, temperatures calculated by the MBT-CBT combination show no difference between the two methods using 


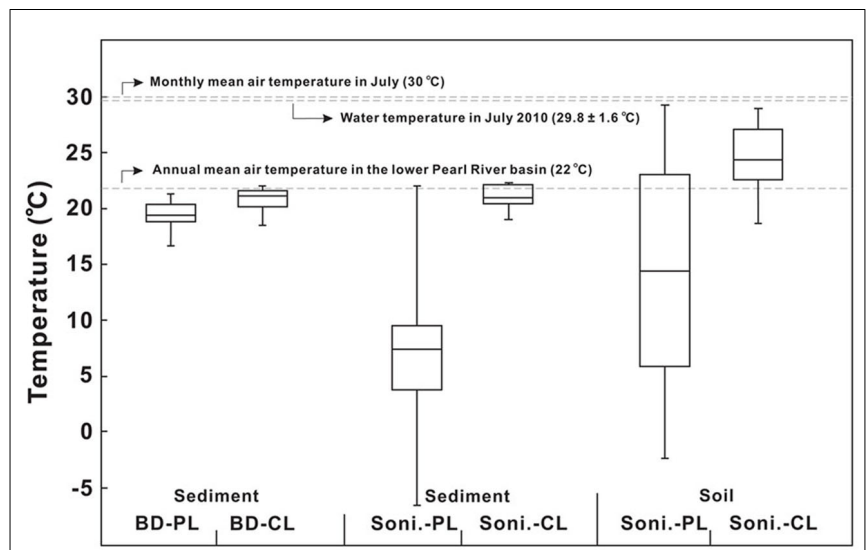

FIGURE 8 | Comparisons of MBT-CBT-derived temperatures from the sonication (Soni) and Bligh and Dyer (BD) methods to measured annual mean air temperature and monthly mean air temperatures of the lower Pearl River drainage basin, and water column temperature in the lower Pearl River and estuary. $C L$, core lipids; $P L$, polar lipids.

\section{REFERENCES}

Ballantyne, A. P., Greenwood, D. R., Sinninghe Damsté, J. S., Csank, A. Z., Eberle, J. J., and Rybczynski, N. (2010). Significantly warmer Arctic surface temperatures during the Pliocene indicated by multiple independent proxies. Geology 38, 603-606.

Belicka, L. L., and Harvey, H. R. (2009). The sequestration of terrestrial organic carbon in Arctic ocean sediments: a comparison of methods and implications for regional carbon budgets. Geochim. Cosmochim. Acta 73, 6231-6248.

Bendle, J. A., Weijers, J. W. H., Maslin, M. A., Sinninghe Damsté, J. S., Schouten, S., Hopmans, E. C., Boot, C. S., and Pancost, R. D. (2010). Major changes in glacial and Holocene terrestrial temperatures and sources of organic carbon recorded in the Amazon fan by tetraether lipids. Geochem. Geophys. Geosyst. 11, Q12007.

Callahan, J., Dai, M., Chen, R.-F., Li, X., Lu, Z., and Huang, W. (2004). Distribution of dissolved organic matter in the Pearl River Estuary, China. Mar. Chem. 89, 211-224.

Chen, J., Jin, H., Yin, K., and Li, Y. (2003). Variation of reactivity of particulate and sedimentary organic matter along the Zhujiang River Estuary. Acta Oceanol. Sin. 22, 557-568.

Chen, J., Li, Y., Yin, K., and Jin, H. (2004). Amino acids in the Pearl River Estuary and the adjacent waters: origins, transformation and degradation. Cont. Shelf Res. 24, 1877-1894.

Cole, J. J., Prairie, Y. T., Caraco, N. F., McDowell, W. H., Tranvik, L. J.,
Strieg, R. G., Duarte, C. M., Kortelainen, P., Downing, J. A., Middelburg, J. J., and Melack, J. (2007). Plumbing the global carbon cycle: integrating inland waters into the terrestrial carbon budget. Ecosystems 10, 171-184.

Dagg, M. J., Bianchi, T. S., Breed, G. A., Cai, W.-J., Duan, S., Liu, H., McKee, B. A., Powell, R. T., and Stewart, C. M. (2005). Biogeochemical characteristics of the lower Mississippi River, USA, during June 2003. Estuaries 28, 664-674.

Donders, T. H., Weijers, J. W. H., Munsterman, D. K., Kloosterboervan Hoeve, M. L., Buchles, L. K., Pancost, R. D., Schouten, S., Sinninghe Damsté, J. S., and Brinkhuis, H. (2009). Strong climate coupling of terrestrial and marine environment in the Miocene of northwest Europe. Earth Planet. Sci. Lett. 281, 215-225.

Duan, S., and Bianchi, T. S. (2006). Seasonal changes in the abundance and composition of plant pigments in particulate organic carbon in the lower Mississippi and Pearl Rivers (USA). Estuaries Coast. 29, 427-442.

Fawcett, P. J., Werne, J. P., Anderson, R. S., Heikoop, J. M., Brown, E. T., Berke, M. A., Smith, S. J., Goff, F., Donohoo-Hurley, L., Cisneros-Dozal, L. M., Schouten, S., Sinninghe Damsté, J. S., Huang, Y., Toney, J., Fessenden, J., WoldeGabriel, G., Atudorei, V., Geissman, J. W., and Allen, C. D. (2011). Extended megadroughts in the southwestern United States during Pleistocene interglacials. Nature 470, 518-521.

the C-bGDGTs; the results of which are close to the mean annual air temperature of the lower PR basin. These results suggest that the MBT-CBT proxies derived from C-bGDGTs may be valid for studying paleo-soil $\mathrm{pH}$ and continental air temperatures in the lower Pearl River drainage basin. On the other hand, temperatures calculated from the P-bGDGTs are significantly lower than those from the C-bGDGTs and may not be reliable indicators of annual MATs.

\section{ACKNOWLEDGMENTS}

We thank Dai L., Li Y., Zhong D., Hong Y., Wong C., and Shao L. for helping with the sampling and analysis of some of the samples collected for this study. Captain Deng was greatly appreciated for helping with the field experiments during the cruise. We would like to thank the two Francien Peterse and Ping'An Peng reviewers and Courtney Warren for constructive comments on an early version of this paper. This research was supported by the South China Sea-Deep program of the National Science Foundation of China (91028005) and the State Key Laboratory of Marine Geology of Tongji University.

Goni, M. A., Monacci, N., Gisewhite, R., Ogston, A., Crockett, J. and Nittrouer, C. (2006). Distribution and sources of particulate organic matter in the water column and sediments of the Fly River Delta, Gulf of Papua (Papua New Guinea). Estuar. Coast. Shelf Sci. 69 2260-2280.

He, B., Dai, M., Huang, W., Liu, Q., Chen, H., and Xu, L. (2010). Sources and accumulation of organic carbon in the Pearl River Estuary surface sediment as indicated by elemental, stable carbon isotopic, and carbohydrate compositions. Biogeosciences 7, 3343-3362.

Hedges, J. I., Clark, W. A., and Cowie, G. L. (1988). Organic matter sources to the water column and surficial sediment of a marine bay. Limnol. Oceanogr. 33, 1116-1136.

Hedges, J. I., and Keil, R. G. (1995). Sedimentary organic matter preservation: an assessment and speculative synthesis. Mar. Chem. 49, 81-115.

Herfort, L., Schouten, S., Boon, J. P., Woltering, M., Baas, M., Weijers, J. W. H., and Sinninghe Damsté, J. S. (2006). Characterization of transport and deposition of terrestrial organic matter in the southern North Sea using the BIT index. Limnol. Oceanogr. 51, 2196-2205.

Hopmans, E. C., Weijers, J. W. H., Schefuss, E., Herfort, L., Sinninghe Damsté, J. S., and Schouten, S. (2004). A novel proxy for terrestrial organic matter in sediments based on branched and isoprenoid tetraether lipids. Earth Planet. Sci. Lett. 224, 107-116.
Hu, J. F., Peng, P. A., and Chivas, A. R. (2009). Molecular biomarker evidence of origins and transport of organic matter in sediments of the Pearl River estuary and adjacent South China Sea. Appl. Geochem. 24, 1666-1676.

Hu, J. F., Peng, P. A., Jia, G. D., Mai, B. X., and Zhang, G. (2006a). Distribution and sources of organic carbon, nitrogen and their isotopes in sediments of the subtropical Pearl River estuary and adjacent shelf, Southern China. Mar. Chem. 98, 274-285.

Hu, J. F., Zhang, H. B., and Peng, P. A. (2006b). Fatty acid composition of surface sediments in the subtropical Pearl River estuary and adjacent shelf, Southern China. Estuar. Coast. Shelf Sci. 66, 346-356.

Huguet, A., Fosse, C., Metzger, P., Fritsch, E., and Derenne, S. (2010a). Occurrence and distribution of extractable glycerol dialkyl glycerol tetraethers in podzols. Org. Geochem. 41, 291-301.

Huguet, C., Martens-Habbena, W., Urakawa, H., Stahl, D. A., and Ingalls, A. E. (2010b). Comparison of extraction methods for quantitative analysis of core and intact polar glycerol dialkyl glycerol tetraethers (GDGTs) in environmental samples. Limnol. Oceanogr. Methods 8, 127-145.

Huguet, C., Smittenberg, R. H., Boer, W., Sinninghe Damsté, J. S., and Scouten, S. (2007). Twentieth century proxy records of temperature and soil organic matter input in the Drammensfjord, southern Norway. Org. Geochem. 38, 1838-1849. 
Jia, G., and Peng, P. (2003). Temporal and spatial variations in signatures of sedimented organic matter in Lingding Bay (Pearl estuary), southern China. Mar. Chem. $82,47-54$.

Kim, J. H., Buscail, R., Bourrin, F., Palanques, A., Sinninghe Damsté, J. S., Bonnin, J., and Schouten, S. (2009). Transport and depositional process of soil organic matter during wet and dry storms on the Tét inner shelf (NW Mediterranean). Palaeogeogr. Palaeoclimatol. Palaeoecol. 273, 228-238.

Kim, J. H., Ludwig, W., Schoutent, S., Kerherve, P., Herfort, L., Bonnin, J., and Sinninghe Damsté, J. S. (2007). Impact of flood events on the transport of terrestrial organic matter to the ocean: a study of the Tét River (SW France) using the BIT index. Org. Geochem. 38, 1593-1606.

Kim, J. H., Schouten, S., Buscail, R., Ludwig, W., Bonnin, J., Sinninghe Damsté, J. S., and Bourrin, F. (2006). Origin and distribution of terrestrial organic matter in the NW Mediterranean (Gulf of Lions): exploring the newly developed BIT index. Geochem. Geophys. Geosyst. 7, $1-20$.

Kim, J. H., Zarzycka, B., Buscail, R., Peters, F., Bonnin, J., Ludwig, W., Schouten, S., and Sinninghe Damsté, J. S. (2010). Contribution of river borne soil organic carbon to the Gulf of Lions (NW Mediterranean). Limnol. Oceanogr. 55, 507-518.

Leininger, S., Urich, T., Schloter, M., Schwark, L., Qi, J., Nicol, G. W., Prosser, J. I., Schuster, S. C., and Schleper, C. (2006). Archaea predominate among ammoniaoxidizing prokaryotes in soils. Nature 442, 806-809.

Liu, X.-L., Leider, A., Gillespie, A., Gröger, J., Versteegh, G. J. M., and Hinrichs, K.-U. (2010). Identification of polar lipid precursors of the ubiquitous branched GDGT orphan lipids in a peat bog in Northern Germany. Org. Geochem. 41, 653-660.

Liu, Z., Colin, C., Phon Le, K., Tong, S., Chen, Z., and Trentesaux, A. (2007). Climatic and tectonic controls on weathering in south China and Indochina Peninsula: clay mineralogical and geochemical investigations from the Pearl, Red, and Mekong drainage basins. Geochem. Geophys. Geosyst. 8, 1-18.

Mayorga, E. (2008). Carbon cycle: harvest of the century. Nature 451, 405-406.

Owen, R. B., and Lee, R. (2004). Human impacts on organic matter sedimentation in a proximal shelf setting,
Hong Kong. Cont. Shelf Res. 24, 583-602.

Pearson, A., Huang, Z., Ingalls, A. E., Romanek, C. S., Wiegel, J., Freeman, K. H., Smittenberg, R. H., and Zhang, C. L. (2004). Nonmarine crenarchaeol in Nevada hot springs. Appl. Environ. Microbiol. 70, 5229-5237.

Peterse, F., Nicol, G. W., Schouten, S., and Sinninghe Damsté, J. S. (2010). Influence of soil $\mathrm{pH}$ on the abundance and distribution of core and intact polar lipid-derived branched GDGTs in soil. Org. Geochem. 41, 1171-1175.

Peterse, F., Prins, M. A., Beets, C. J., Troelstra, S. R., Zheng, H., Gu, Z., Schouten, S., and Sinninghe Damsté, J. S. (2011). Decoupled warming and monsoon precipitation in East Asia over the last deglaciation. Earth Planet. Sci. Lett. 301, 256-264.

Peterse, F., Schouten, S., van der Meer, J., van der Meer, M. T. J., and Sinninghe Damsté, J. S. (2009). Distribution of branched tetraether lipids in geothermally heated soils: implications for the MBT/CBT temperature proxy. Org. Geochem. 40, 201-205.

Pitcher, A., Hopmans, E. C., Schouten, S., and Sinninghe Damsté, J. S. (2009). Separation of core and intact polar archaeal tetraether lipids using silica columns: insights into living and fossil biomass contributions. Org. Geochem. 40, 12-19.

Powers, L. A., Werne, J. P., Johnson, T. C., Hopmans, E. C., Sinninghe Damsté, J. S., and Schouten, S. (2004). Crenarchaeotal membrane lipids in lake sediments: a new paleotemperature proxy for continental paleoclimate reconstruction? Geology 32, 613-616.

Raymond, P. A., and Cole, J. J. (2003). Increase in the export of alkalinity from North America's largest river. Science 301, 88-91.

Rueda, G., Rosell-Melé, A., Escala, M., Gyllencreutz, R., and Backman, J. (2009). Comparison of instrumental and GDGT-based estimates of sea surface and air temperatures from the Skagerrak. Org. Geochem. 40, 287-291.

Schmidt, F., Hinrichs, K.-U., and Elvert, M. (2010). Sources, transport, and partitioning of organic matter at a highly dynamic continental margin. Mar. Chem. 118, 37-55.

Schouten, S., Eldrett, J., Greenwood, D. R., Harding, I., Baas, M., and Sinninghe Damsté, J. S. (2008). Onset of long-term cooling of Greenland near the Eocene-Oligocene boundary as revealed by branched tetraether lipids. Geology 36, 147-150.
Schouten, S., Huguet, C., Hopmans, E. C., and Sinninghe Damsté, J. S. (2007). Improved analytical methodology of the $\mathrm{TEX}_{86}$ paleothermometry by high performance liquid chromatography atmospheric pressure chemical ionization-mass spectrometry. Anal. Chem. 79, 2940-2944.

Sinninghe Damsté, J. S., Ossebaar, J. Abbas, B., Schouten, S., and Verschuren, D. (2009). Fluxes and distribution of tetraether lipids in an equatorial African lake: constraints on the application of the $\mathrm{TEX}_{86}$ palaeothermometer and BIT index in lacustrine settings. Geochim. Cosmochim. Acta 73, 4232-4249.

Sinninghe Damsté, J. S., Rijpstra, W. I. C., Hopmans, E. C., Weijers, W. H., Foesel, B. U., Overmann, J., and Dedysh, S. N. (2011). 13,16-dimethyl octacosanedioic acid (iso-diabolic acid), a common membrane-spanning lipid of Acidobacteria subdivisions 1 and 3. Appl. Environ. Microbiol. 77, 4147-4154.

Smith, R. W., Bianchi, T. S., and Savage, C. (2010). Comparison of lignin phenols and branched/isoprenoid tetraethers (BIT index) as indices of terrestrial organic matter in Doubtful Sound, Fiordland, New Zealand. Org. Geochem. 41, 281-290.

Sun, Q., Chu, G., Liu, M., Xie, M., Li, S., Ling, Y., Wang, X., Shi, L., Jia, G., and Lü, H. (2011). Distributions and temperature dependence of branched glycerol dialkyl glycerol tetraethers in recent lacustrine sediments from China and Nepal. $J$. Geophys. Res. 116, G01008.

Tierney, J. E., and Russell, J. M. (2009). Distributions of branched GDGTs in a tropical lake system: implications for lacustrine application of the MBT/CBT paleoproxy. Org. Geochem. 40, 1032-1036.

Tierney, J. E., Schouten, S., Pitcher, A., Hopmans, E. C., and Sinninghe Damsté, J. S. (2011). Core and intact polar glycerol dialkyl glycerol tetraethers (GDGTs) in Sand Pond, Warwick, Rhode Island (USA): insights into the origin of lacustrine GDGTs. Geochim. Cosmochim. Acta doi:10.1016/j.gca.2011.10.018.

Tyler, J. J., Nederbragt, A. J., Jones, V. J., and Thurow, J. W. (2010). Assessing past temperature and soil $\mathrm{pH}$ estimates from bacterial tetraether membrane lipids: evidence from the recent lake sediments of Lochnagar, Scotland. J. Geophys. Res. 115, G01015.

van Dongen, B. E., Semiletov, I., Weijers, J. W. H., and Gustafsson, O. (2008).
Contrasting lipid biomarker composition of terrestrial organic matter exported from across the Eurasian Arctic by the five great Russian Arctic rivers. Global Biogeochem. Cycles 22, GB1011.

Wai, O. W. H., Wang, C. H., Li, Y. S., and Li, X. D. (2004). The formation mechanisms of turbidity maximum in the Pearl River estuary, China. Mar. Pollut. Bull. 48, 441-448.

Walsh, E. M., Ingalls, A. E., and Keil, R. G. (2008). Sources and transport of terrestrial organic matter in Vancouver Island fjords and the Vancouver-Washington Margin: a multiproxy approach using $\delta^{13} \mathrm{C}$ (org), lignin phenols, and the ether lipid BIT index. Limnol. Oceanogr. 53, 1054-1063.

Wang, H., Liu, W., Zhang, C. L., Wang, Z., Wang, J., Liu, Z., and Dong, H. (2012). Distribution of glycerol dialkyl glycerol tetraethers (GDGTs) in surface sediments of Lake Qinghai and surrounding soils. Org. Geochem. (in press).

Weijers, J. W. H., Bernhardt, B., Peterse, F., Werne, J. P., Dungait, J. A. J. Schouten, S., and Sinninghe Damsté, J. S. (2011). Absence of seasonal patterns in MBT-CBT indices in midlatitude soils. Geochim. Cosmochim. Acta 75, 3179-3190.

Weijers, J. W. H., Schouten, S., Schefuß, E., Schneider, R. R., and Sinninghe Damsté, J. S. (2009). Disentangling marine, soil and plant organic carbon contributions to continental margin sediments: a multi-proxy approach in a 20,000 year sediment record from the Congo deep-sea fan. Geochim. Cosmochim. Acta 73, 119-132.

Weijers, J. W. H., Schouten, S., Spaargaren, O. C., and Sinninghe Damsté, J. S. (2006a). Occurrence and distribution of tetraether membrane lipids in soils: implications for the use of the $\mathrm{TEX}_{86}$ proxy and the BIT index. Org. Geochem. 37, 1680-1693.

Weijers, J. W. H., Schouten, S., Hopmans, E. C., Geenevasen, J. A. J., David, O. R. P., Coleman, J. M., Pancost, R. D., and Sinninghe Damsté, J. S. (2006b). Membrane lipids of mesophilic anaerobic bacteria thriving in peats have typical archaeal traits. Environ. Microbiol. 8, 648-657.

Weijers, J. W. H., Schouten, S., van den Donker, J. C., Hopmans, E. C., and Sinninghe Damsté, J. S. (2007a). Environmental controls on bacterial tetraether membrane lipid distribution in soils. Geochim. Cosmochim. Acta 71, 703-713. 
Weijers, J. W. H., Schefuß, E., Schouten, S., and Sinninghe Damsté, J. S. (2007b). Coupled thermal and hydrological evolution of tropical Africa over the last deglaciation. Science 315, 1701-1704.

Weijers, J. W. H., Schouten, S., Sluijs, A., Brinkhuis, H., and Sinninghe Damsté, J. S. (2007c). Warm Arctic continents during the PalaeoceneEocene thermal maximum. Earth Planet. Sci. Lett. 261, 230-238.

White, D. C., Davis, W. M., Nickels, J. S., King, J. D., and Bobbie, R. J. (1979). Determination of the sedimentary microbial biomass by extractable lipid phosphate. Oecologia $40,51-62$.

Wong, S. C., Li, X. D., Zhang, G., Qi, S. H., and Min, Y. S. (2002). Heavy metals in agricultural soils of the Pearl River Delta, South China. Environ. Pollut. 119, 33-44.

Xiao, J. L., Chang, Z. G., Si, B., Qin, X. G., Itoh, S., and Lomtatidze, Z. (2009). Partitioning of the grain-size components of Dali Lake core sediments: evidence for lake-level changes during the Holocene. J. Paleolimnol. 42, 249-260.
Yu, F., Zong, Y., Lloyd, J. M., Huang, G., Leng, M., Kendrick, C., Lamb, A. L., and Yim, W. W.-S. (2010). Bulk organic $\delta 13 \mathrm{C}$ and $\mathrm{C} / \mathrm{N}$ as indicators for sediment sources in the Pearl River delta and estuary, southern China. Estuar. Coast. Shelf Sci. 87, 618-630.

Zhang, C. L., Pearson, A., Li, Y.-L., Mills, G., and Wiegel, J. (2006). Thermophilic temperature optimum for crenarchaeol synthesis and its implication for archaeal evolution. Appl. Environ. Microbiol. 72, 4419-4422.

Zhang, S., Lu, X., Higgitt, D. L., Chen, C. A., Han, J., and Sun, H. (2008). Recent changes of water discharge and sediment load in the Zhujiang (Pearl River) Basin, China. Glob. Planet. Change 60, 365-380.

Zhou, H., Hu, J., Ming, L., Peng, P., and Zhang, G. (2011). Branched glycerol dialkyl glycerol tetraethers and paleoenvironmental reconstruction in Zoigê peat sediments during the last 150 years. Chin. Sci. Bull. 56, 2456-2463.

Zhu, C., Wang, Z. H., Xue, B., Yu, P. S., Pan, J. M., Wagner, T., and
Pancost, R. D. (2011a). Characterizing the depositional settings for sedimentary organic matter distributions in the Lower Yangtze River-East China Sea Shelf System. Estuar. Coast. Shelf Sci. 93, 182-191.

Zhu, C., Weijers, J. W. H., Wagner, T., Pan, J.-M., Chen, J.-F., and Pancost, R. D. (2011b). Sources and distributions of tetraether lipids in surface sediments across a large riverdominated continental margin. Org. Geochem. 42, 376-386.

Zimmerman, A. R., and Canuel, E. A. (2001). Bulk organic matter and lipid biomarker composition of Chesapeake Bay surficial sediments as indicators of environmental processes. Estuar. Coast. Shelf Sci. 53, 319-341.

Zink, K.-G., Vandergoes, M. J., Mangelsdorf, K., Dieffenbacher-Krall, A. C., and Schwark, L. (2010) Application of bacterial glycerol dialkyl glycerol tetraethers (GDGTs) to develop modern and past temperature estimates from $\mathrm{New}$ Zealand lakes. Org. Geochem. 41, 1060-1066.
Conflict of Interest Statement: The authors declare that the research was conducted in the absence of any commercial or financial relationships that could be construed as a potential conflict of interest.

Received: 08 August 2011; accepted: 22 December 2011; published online: 09 January 2012.

Citation: Zhang CL, Wang J, Wei Y, Zhu C, Huang L and Dong H (2012) Production of branched tetraether lipids in the lower Pearl River and estuary: effects of extraction methods and impact on bGDGT proxies. Front. Microbio. 2:274 doi: 10.3389/fmicb.2011.00274

This article was submitted to Frontiers in Terrestrial Microbiology, a specialty of Frontiers in Microbiology.

Copyright () 2012 Zhang, Wang, Wei, Zhu, Huang and Dong. This is an openaccess article distributed under the term of the Creative Commons Attribution Non Commercial License, which permits non-commercial use, distribution, and reproduction in other forums, provided the original authors and source are credited. 


\section{APPENDIX}

Table A1 | Sonication extraction-derived bGDGTs and proxies for sediment samples.

\begin{tabular}{|c|c|c|c|c|c|c|c|c|c|c|c|c|c|c|}
\hline \multirow[t]{3}{*}{ Samples $^{\S}$} & \multicolumn{9}{|c|}{ bGDGTs (\%) } & \multicolumn{4}{|c|}{ bGDGT proxies ${ }^{\ddagger}$} & \multirow[t]{3}{*}{ BIT } \\
\hline & \multirow{2}{*}{$\begin{array}{l}\text { GDGT-III } \\
\text { m/z } 1050\end{array}$} & \multirow{2}{*}{$\begin{array}{l}\text { GDGT-IIIb } \\
\text { m/z } 1048\end{array}$} & \multirow{2}{*}{$\begin{array}{l}\text { GDGT-IIIc } \\
\text { m/z } 1046\end{array}$} & \multirow{2}{*}{$\begin{array}{l}\text { GDGT-II } \\
\text { m/z } 1036\end{array}$} & \multirow{2}{*}{$\begin{array}{l}\text { GDGT-Ilb } \\
\text { m/z } 1034\end{array}$} & \multirow{2}{*}{$\begin{array}{l}\text { GDGT-Ilc } \\
\text { m/z } 1032\end{array}$} & \multirow{2}{*}{$\begin{array}{l}\text { GDGT-I } \\
\text { m/z } 1022\end{array}$} & \multirow{2}{*}{$\begin{array}{l}\text { GDGT-Ib } \\
\text { m/z } 1020\end{array}$} & \multirow{2}{*}{$\begin{array}{l}\text { GDGT-Ic } \\
\text { m/z } 1018\end{array}$} & \multirow[t]{2}{*}{ MBT } & \multirow[t]{2}{*}{ CBT } & \multirow{2}{*}{\multicolumn{2}{|c|}{$\begin{array}{l}\mathrm{T}_{\mathrm{MBT} / \mathrm{CB} T} \mathrm{pH}_{\mathrm{CBT}} \\
\left({ }^{\circ} \mathrm{C}\right)\end{array}$}} & \\
\hline & & & & & & & & & & & & & & \\
\hline PR-sedi-9-CL & 3.52 & 0.50 & 0.09 & 26.40 & 6.49 & 0.75 & 49.50 & 10.82 & 1.93 & 0.62 & 0.64 & 19.0 & 7.1 & 0.94 \\
\hline PR-sedi-8-CL & 2.68 & 0.34 & 0.18 & 22.25 & 5.24 & 0.75 & 54.03 & 12.46 & 2.07 & 0.69 & 0.63 & 22.2 & 7.1 & 0.93 \\
\hline PR-sedi-10-CL & 3.96 & 0.47 & 0.22 & 23.50 & 5.87 & 0.86 & 50.13 & 12.64 & 2.36 & 0.65 & 0.60 & 20.9 & 7.2 & 0.88 \\
\hline PR-sedi-7-CL & 3.08 & 0.42 & 0.13 & 23.32 & 5.22 & 0.65 & 53.08 & 11.83 & 2.28 & 0.67 & 0.65 & 21.4 & 7.0 & 0.86 \\
\hline PR-sedi-6-CL & 4.54 & 0.48 & 0.27 & 23.65 & 5.89 & 0.65 & 49.72 & 12.00 & 2.79 & 0.65 & 0.61 & 20.4 & 7.2 & 0.79 \\
\hline PR-sedi-5-CL & 4.32 & 0.64 & 0.33 & 21.80 & 5.53 & 0.65 & 51.37 & 12.65 & 2.71 & 0.67 & 0.60 & 21.6 & 7.2 & 0.76 \\
\hline PR-sedi-4-CL & 5.46 & n.d. ${ }^{\dagger}$ & n.d. & 19.59 & 5.62 & 1.07 & 52.93 & 11.71 & 3.63 & 0.68 & 0.62 & 22.2 & 7.1 & 0.69 \\
\hline PR-sedi-3-CL & 4.69 & 0.50 & 0.29 & 23.73 & 5.92 & 0.95 & 48.53 & 12.32 & 3.07 & 0.64 & 0.60 & 20.3 & 7.2 & 0.65 \\
\hline PR-sedi-2-CL & 5.15 & 1.02 & n.d. & 19.51 & 6.04 & 1.05 & 51.33 & 12.68 & 3.22 & 0.67 & 0.58 & 22.1 & 7.2 & 0.58 \\
\hline PR-sedi-1-CL & 5.10 & 0.67 & 0.20 & 22.47 & 5.90 & 0.87 & 49.54 & 12.35 & 2.89 & 0.65 & 0.60 & 20.7 & 7.2 & 0.71 \\
\hline PR-sedi-11-CL & 5.51 & 0.81 & n.d. & 22.88 & 7.42 & 1.27 & 45.67 & 13.16 & 3.28 & 0.62 & 0.52 & 20.1 & 7.4 & 0.40 \\
\hline PR-sedi-12-CL & 5.27 & 0.60 & 0.23 & 21.80 & 7.40 & 1.31 & 46.73 & 12.94 & 3.72 & 0.63 & 0.53 & 20.7 & 7.4 & 0.52 \\
\hline PR-sedi-14-CL & 5.72 & 0.60 & n.d. & 20.82 & 5.07 & 1.07 & 45.64 & 13.58 & 7.51 & 0.67 & 0.55 & 22.1 & 7.3 & 0.12 \\
\hline PR-sedi-9-PL & 12.50 & 1.20 & 0.59 & 37.65 & 4.95 & 0.35 & 34.55 & 7.67 & 0.54 & 0.43 & 0.76 & 8.2 & 6.8 & 0.88 \\
\hline PR-sedi-8-PL & 22.77 & 0.73 & 0.12 & 46.16 & 2.07 & 0.77 & 23.15 & 2.42 & 1.81 & 0.27 & 1.19 & -3.5 & 5.6 & 0.83 \\
\hline PR-sedi-10-PL & 11.52 & 3.29 & 0.13 & 34.11 & 4.49 & 1.08 & 35.44 & 7.66 & 2.28 & 0.45 & 0.76 & 9.5 & 6.8 & 0.83 \\
\hline PR-sedi-7-PL & 20.00 & 0.54 & 1.42 & 31.87 & 2.79 & 0.02 & 40.92 & 2.42 & 0.01 & 0.43 & 1.15 & 4.9 & 5.7 & 0.84 \\
\hline PR-sedi-6-PL & 5.08 & 2.53 & 1.34 & 39.48 & 8.86 & 5.06 & 23.18 & 8.27 & 6.21 & 0.38 & 0.56 & 7.5 & 7.3 & 0.76 \\
\hline PR-sedi-5-PL & 6.55 & 5.70 & 0.78 & 63.94 & 7.89 & 1.77 & 6.52 & 4.36 & 2.48 & 0.13 & 0.76 & -6.5 & 6.8 & 0.70 \\
\hline PR-sedi-4-PL & 4.91 & n.d. & n.d. & 25.73 & 6.06 & 0.77 & 47.59 & 12.57 & 2.36 & 0.63 & 0.60 & 19.6 & 7.2 & 0.75 \\
\hline PR-sedi-3-PL & 19.69 & 4.37 & 1.57 & 9.45 & 4.55 & 0.80 & 31.94 & 22.81 & 4.81 & 0.60 & 0.18 & 22.0 & 8.3 & 0.34 \\
\hline PR-sedi-2-PL & 4.85 & 0.94 & 0.47 & 49.71 & 4.51 & 0.53 & 30.72 & 7.92 & 0.35 & 0.39 & 0.81 & 5.8 & 6.6 & 0.65 \\
\hline PR-sedi-1-PL & 9.64 & 3.49 & 1.19 & 44.43 & 6.17 & 0.41 & 27.97 & 5.33 & 1.36 & 0.35 & 0.80 & 3.8 & 6.7 & 0.65 \\
\hline PR-sedi-11-PL & 7.86 & 3.35 & 2.82 & 37.99 & 9.30 & 1.56 & 20.52 & 11.30 & 5.30 & 0.37 & 0.45 & 8.2 & 7.6 & 0.31 \\
\hline PR-sedi-12-PL & 12.64 & 4.21 & 2.51 & 27.51 & 4.79 & 0.74 & 31.64 & 10.77 & 5.20 & 0.48 & 0.58 & 12.3 & 7.2 & 0.53 \\
\hline PR-sedi-14-PL & 9.55 & 2.08 & n.d. & 48.60 & 6.51 & 1.86 & 22.56 & 6.31 & 2.52 & 0.31 & 0.74 & 2.6 & 6.8 & 0.35 \\
\hline
\end{tabular}

CL, core lipids; PL, polar lipids.

s See Figure 1 for sample locations, which are the same as filter samples (solid black circles).

${ }^{+}$Not detected.

${ }^{*}$ CBT-pH and MBT-CBT temperature were calculated according to Weijers et al. (2007a). See text for formulas. 
Table A2 | Bligh and Dyer method-derived bGDGTs and proxies for sediment samples.

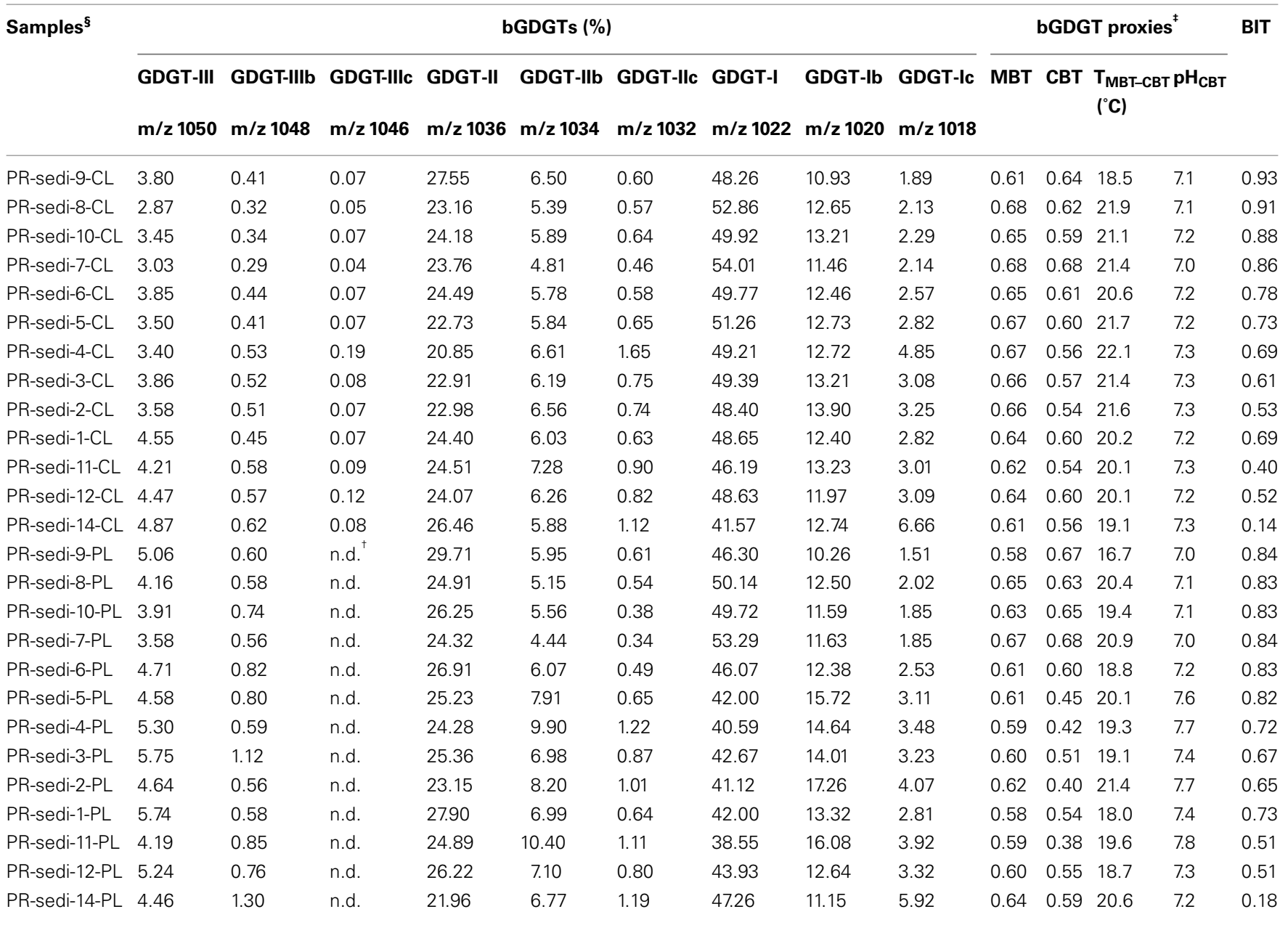

$C L$, core lipids; $P L$, polar lipids.

${ }^{s}$ See Figure 1 for sample locations, which are the same as filter samples (solid black circles).

${ }^{+}$Not detected.

${ }^{\ddagger}$ CBT-pH and MBT-CBT temperature were calculated according to Weijers et al. (2007a). See text for formulas. 
Table A3 | Sonication extraction-derived bGDGTs and proxies for soil samples.

\begin{tabular}{|c|c|c|c|c|c|c|c|c|c|c|c|c|c|c|}
\hline Samples $^{\S}$ & \multicolumn{9}{|c|}{ bGDGTs (\%) } & \multicolumn{4}{|c|}{ bGDGT proxies $^{\ddagger}$} & BIT \\
\hline PR-Soil-19-CL & 2.39 & n.d. ${ }^{+}$ & n.d. & 14.68 & 2.34 & 0.75 & 70.20 & 7.57 & 2.09 & 0.80 & 0.93 & 25.1 & 6.3 & 0.92 \\
\hline PR-Soil-16-CL & 4.15 & 0.56 & 0.35 & 26.81 & 9.27 & 0.55 & 42.29 & 14.04 & 1.98 & 0.58 & 0.47 & 18.6 & 7.5 & 0.69 \\
\hline PR-Soil-12-CL & 5.79 & 0.73 & n.d. & 21.63 & 7.24 & 1.04 & 43.53 & 16.15 & 3.89 & 0.64 & 0.44 & 21.5 & 7.6 & 0.81 \\
\hline PR-Soil-11-CL & 3.68 & n.d. & n.d. & 15.58 & 9.89 & 1.57 & 40.38 & 23.13 & 5.78 & 0.69 & 0.23 & 26.4 & 8.2 & 0.58 \\
\hline PR-Soil-7-CL & 3.57 & n.d. & n.d. & 19.51 & 8.49 & 1.52 & 42.83 & 18.60 & 5.49 & 0.67 & 0.36 & 24.0 & 7.8 & 0.86 \\
\hline PR-Soil-8-CL & 2.07 & n.d. & n.d. & 14.38 & 2.65 & 0.65 & 65.98 & 11.39 & 2.88 & 0.80 & 0.76 & 26.9 & 6.8 & 0.92 \\
\hline PR-Soil-9-CL & 0.98 & 0.12 & n.d. & 10.42 & 2.19 & 0.33 & 75.48 & 7.69 & 2.79 & 0.86 & 0.94 & 28.1 & 6.3 & 0.58 \\
\hline PR-Soil-1-CL & 0.45 & 0.26 & n.d. & 7.76 & 0.15 & 0.00 & 90.90 & 0.43 & 0.05 & 0.91 & 2.23 & 18.7 & 2.9 & 0.97 \\
\hline PR-Soil-2-CL & 2.50 & 0.21 & n.d. & 19.37 & 3.50 & 0.41 & 59.85 & 12.11 & 2.04 & 0.74 & 0.71 & 24.3 & 6.9 & 0.84 \\
\hline PR-Soil-6-CL & 1.81 & 0.29 & n.d. & 13.67 & 3.28 & 0.72 & 63.26 & 13.28 & 3.68 & 0.80 & 0.67 & 27.8 & 7.0 & 0.93 \\
\hline PR-Soil-10-CL & 4.68 & 0.45 & n.d. & 20.08 & 5.21 & 0.97 & 51.58 & 13.92 & 3.12 & 0.69 & 0.57 & 22.8 & 7.3 & 0.88 \\
\hline PR-Soil-13-CL & 3.13 & 0.54 & 0.13 & 22.45 & 4.96 & 0.56 & 57.53 & 9.24 & 1.47 & 0.68 & 0.75 & 21.0 & 6.8 & 0.96 \\
\hline PR-Soil-17-CL & 5.46 & n.d. & n.d. & 19.31 & 9.90 & 2.14 & 37.74 & 19.59 & 5.87 & 0.63 & 0.29 & 22.8 & 8.0 & 0.80 \\
\hline PR-Soil-18-CL & 0.28 & 0.05 & 0.16 & 5.89 & 0.51 & 0.60 & 89.94 & 1.47 & 1.08 & 0.92 & 1.68 & 24.4 & 4.3 & 0.93 \\
\hline PR-Soil-20-CL & 0.23 & n.d. & n.d. & 3.67 & n.d. & n.d. & 95.28 & 0.62 & 0.21 & 0.96 & 2.21 & 21.3 & 3.0 & 0.97 \\
\hline PR-Soil-19-PL & 2.88 & 1.53 & n.d. & 15.23 & 1.80 & 0.80 & 65.28 & 9.74 & 2.74 & 0.78 & 0.84 & 24.9 & 6.5 & 0.97 \\
\hline PR-Soil-16-PL & 4.53 & 2.54 & 1.03 & 29.59 & 9.67 & 3.91 & 39.66 & 4.83 & 4.24 & 0.49 & 0.68 & 11.9 & 7.0 & 0.85 \\
\hline PR-Soil-15-PL & 6.45 & 0.99 & n.d. & 21.06 & 13.18 & 0.71 & 35.55 & 18.98 & 3.09 & 0.58 & 0.25 & 20.4 & 8.1 & 0.76 \\
\hline PR-Soil-4-PL & 5.33 & 0.44 & 0.38 & 5.93 & 0.89 & 0.69 & 83.59 & 1.84 & 0.90 & 0.86 & 1.51 & 22.9 & 4.8 & 1.00 \\
\hline PR-Soil-3-PL & 0.38 & 1.19 & 0.08 & 10.33 & 2.26 & 0.30 & 71.85 & 10.92 & 2.69 & 0.85 & 0.79 & 29.2 & 6.7 & 0.71 \\
\hline PR-Soil-1-PL & 3.19 & 4.06 & n.d. & 11.37 & 1.12 & n.d. & 63.39 & 13.95 & 2.92 & 0.80 & 0.70 & 27.5 & 6.9 & 0.96 \\
\hline PR-Soil-2-PL & 9.60 & 4.70 & n.d. & 16.70 & 3.86 & 1.47 & 58.09 & 4.32 & 1.25 & 0.64 & 0.96 & 16.7 & 6.2 & 0.99 \\
\hline PR-Soil-6-PL & 12.66 & 3.04 & n.d. & 36.12 & 2.46 & 0.25 & 41.80 & 2.89 & 0.78 & 0.45 & 1.16 & 5.8 & 5.7 & 0.93 \\
\hline PR-Soil-10-PL & 8.96 & 0.99 & n.d. & 45.31 & 6.59 & 0.21 & 26.91 & 10.77 & 0.26 & 0.38 & 0.62 & 7.1 & 7.1 & 0.84 \\
\hline PR-Soil-13-PL & 3.50 & 0.34 & 0.05 & 19.28 & 3.38 & 0.35 & 60.33 & 10.67 & 2.08 & 0.73 & 0.75 & 23.4 & 6.8 & 1.00 \\
\hline PR-Soil-17-PL & 5.60 & n.d. & n.d. & 25.47 & 12.11 & 4.47 & 36.38 & 9.14 & 6.84 & 0.52 & 0.46 & 15.7 & 7.5 & 0.62 \\
\hline PR-Soil-18-PL & 0.93 & 2.37 & 1.85 & 9.51 & 1.10 & 0.42 & 80.13 & 2.99 & 0.69 & 0.84 & 1.34 & 23.3 & 5.2 & 0.81 \\
\hline PR-Soil-20-PL & 15.85 & n.d. & n.d. & 10.54 & n.d. & n.d. & 70.38 & 2.33 & 0.91 & 0.74 & 1.54 & 16.3 & 4.7 & 0.92 \\
\hline
\end{tabular}

$C L$, core lipids; $P L$, polar lipids.

${ }^{\text {s }}$ See Figure 1 for sample locations (solid white squares).

${ }^{\dagger}$ Not detected.

${ }^{\ddagger}$ CBT-pH and MBT-CBT temperature were calculated according to Weijers et al. (2007a). See text for formulas. 


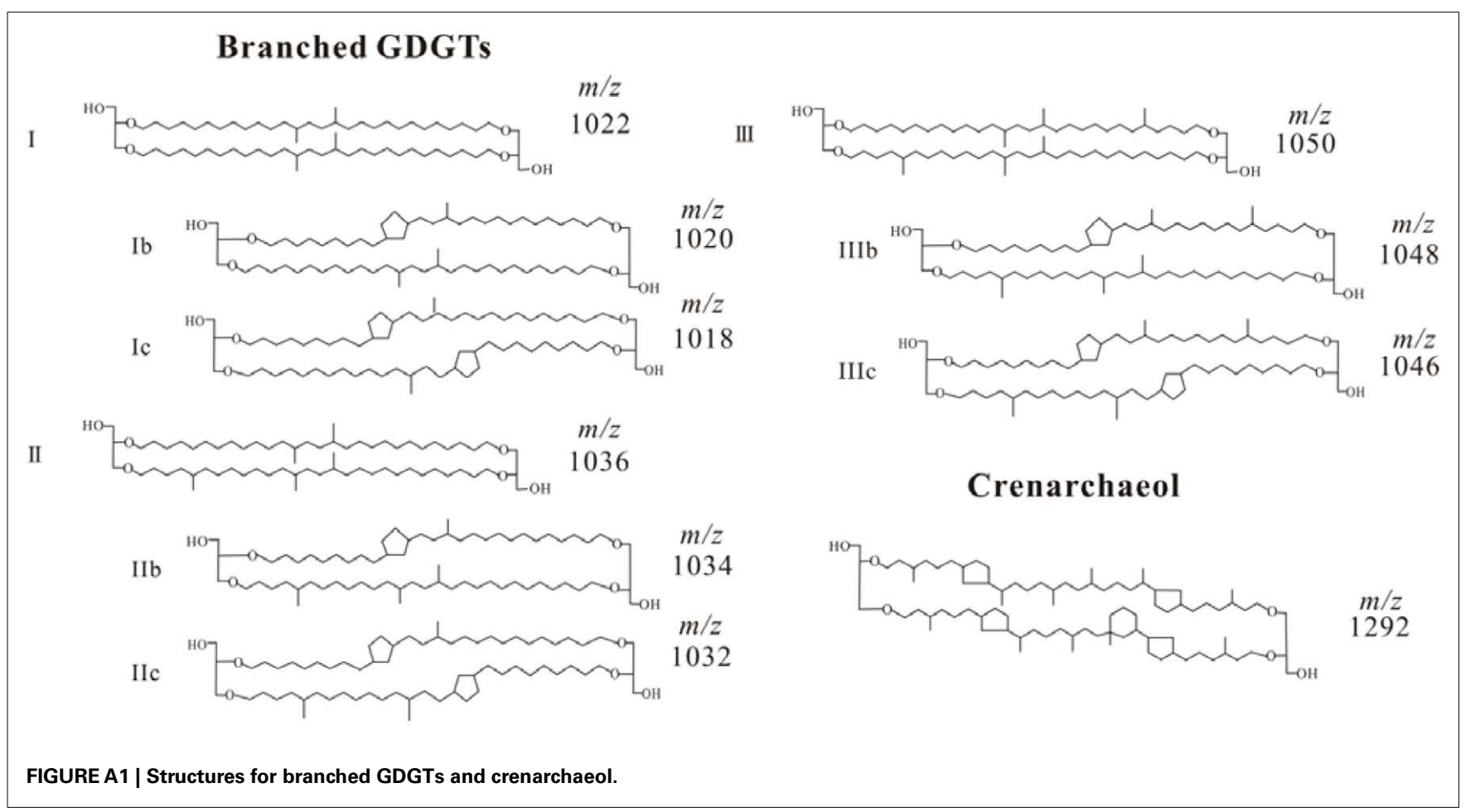

